\title{
REVIEW
}

Open Access

\section{Patient and observer reported outcome measures to evaluate health-related quality of life in inherited metabolic diseases: a scoping review}

Carlota Pascoal ${ }^{1,2,3}$, Sandra Brasil ${ }^{1,2,3}$, Rita Francisco ${ }^{1,2,3}$, Dorinda Marques-da-Silva ${ }^{1,2,3}$, Agnes Rafalko ${ }^{4}$, Jaak Jaeken ${ }^{5}$, Paula A. Videira ${ }^{1,2,3}$, Luísa Barros ${ }^{2,6}$ and Vanessa dos Reis Ferreira ${ }^{1,2^{*}}$

\begin{abstract}
Background: Health-related Quality of Life (HrQoL) is a multidimensional measure, which has gained clinical and social relevance. Implementation of a patient-centred approach to both clinical research and care settings, has increased the recognition of patient and/or observer reported outcome measures (PROMs or ObsROMs) as informative and reliable tools for HrQoL assessment. Inherited Metabolic Diseases (IMDs) are a group of heterogeneous conditions with phenotypes ranging from mild to severe and mostly lacking effective therapies. Consequently, HrQoL evaluation is particularly relevant.
\end{abstract}

Objectives: We aimed to: (1) identify patient and/or caregiver-reported HrQoL instruments used among IMDs; (2) identify the main results of the application of each HrQoL tool and (3) evaluate the main limitations of HrQoL instruments and study design/methodology in IMDs.

Methods: A scoping review was conducted using methods outlined by Arksey and O'Malley. Additionally, we critically analysed each article to identify the HrQoL study drawbacks.

Results: Of the 1954 studies identified, 131 addressed HrQoL of IMDs patients using PROMs and/or ObsROMs, both in observational or interventional studies. In total, we identified $32 \mathrm{HrQoL}$ instruments destined to self- or proxycompletion; only 2\% were disease-specific. Multiple tools (both generic and disease-specific) proved to be responsive to changes in HrQoL; the SF-36 and PedsQL questionnaires were the most frequently used in the adult and pediatric populations, respectively. Furthermore, proxy data often demonstrated to be a reliable approach complementing self-reported HrQoL scores. Nevertheless, numerous limitations were identified especially due to the rarity of these conditions.

Conclusions: HrQoL is still not frequently assessed in IMDs. However, our results show successful examples of the use of patient-reported $\mathrm{HrQoL}$ instruments in this field. The importance of $\mathrm{HrQoL}$ measurement for clinical research and therapy development, incites to further research in HrQoL PROMs' and ObsROMs' creation and validation in IMDs.

Keywords: Patient reported outcome measures (PROMs), Observer reported outcome measures (ObsROMs), Quality of life (QoL), Health-related quality of life (HrQoL), Inherited metabolic disease(s) (IMD(s))

\footnotetext{
* Correspondence: sindromecdg@gmail.com

'Portuguese Association for Congenital Disorders of Glycosylation (CDG), Departamento Ciências da Vida, Faculdade de Ciências e Tecnologia, Universidade NOVA de Lisboa, 2829-516 Caparica, Portugal

${ }^{2}$ CDG \& Allies - Professionals and Patient Associations International Network (PPAIN), Departamento Ciências da Vida, Faculdade de Ciências e Tecnologia, Universidade NOVA de Lisboa, 2829-516 Caparica, Portugal

Full list of author information is available at the end of the article
}

(c) The Author(s). 2018 Open Access This article is distributed under the terms of the Creative Commons Attribution 4.0 International License (http://creativecommons.org/licenses/by/4.0/), which permits unrestricted use, distribution, and reproduction in any medium, provided you give appropriate credit to the original author(s) and the source, provide a link to the Creative Commons license, and indicate if changes were made. The Creative Commons Public Domain Dedication waiver (http://creativecommons.org/publicdomain/zero/1.0/) applies to the data made available in this article, unless otherwise stated. 


\section{Background}

Rare diseases are usually characterized by striking heterogeneity and complexity associated with a lack of evidence-based data and access to clinical experts. This makes it difficult for patients and caregivers to guide their decisions about disease management [1]. These factors have a tremendous impact on patients' health-related quality of life (HrQoL) [2]. HrQoL is defined as a multidimensional concept referring to the subjective evaluation of the impact of the health status in domains related to physical, mental, emotional, and social functioning. It goes beyond direct measures of population health, life expectancy, and causes of death [3]. Patient-centred care is a recent approach in research and clinical practice [4]. One of the ways in which this concept has been advanced is through the development of patient or observer reported outcome measures (PROMs or ObsROMs, respectively). PROMs are direct reports from patients regarding their health condition registered via validated questionnaires with robust psychometric properties [5]. ObsROMs are reports made by a proxy who is in direct contact with the patient when it is not possible to obtain self-reports [6].

PROMs have numerous applications in diverse settings, including research, policy decision-making or treatment effectiveness assessment [7-9]. Besides facilitating communication between patients and clinicians (which improves healthcare provision), they can also improve patient outcomes [10]. Importantly, the use of PROMs is highly supported by regulatory agencies, such as the European Medicine Agency (EMA) and the Food and Drug Administration (FDA) [5, 11]. They are frequently used in clinical trials, mainly as surrogate endpoints $[12,13]$. Among other parameters and variables, PROMs can be used to evaluate HrQoL [13-15]. While PROMs and ObsROMs are often used in common chronic conditions [16, 17], these tools have not often been applied or even developed in rare diseases, due to their specificities $[6,18,19]$. However, there are a few examples of the successful use of PROMs in rare diseases, particularly in academia, by PROM methodologists, and in collaboration with patient organizations [6,20].

There is a need for PROMs in rare inherited metabolic disorders (IMDs), a group of more than 1000 heterogeneous and often life-threatening diseases [21]. The introduction of newborn screening programs detecting currently more than 50 IMDs and the development of new therapies, increased survival, prevalence, and improved patient outcomes [22, 23]. However, living with an IMD affects the patients' HrQoL due to the wide range of diverse and debilitating symptoms and their chronic restrictive diets [24]. Moreover, the natural history of many IMDs is not well defined. This hampers the establishment of care guidelines. Most importantly, a curative treatment is rarely available. Subsequently, patients are generally confronted with a low HrQoL. Without adequate PROMs it is difficult to robustly monitor both symptoms and therapies in IMDs.
PROMs that specifically assess $\mathrm{HrQoL}$ are a particularly relevant outcome in chronic and debilitating conditions, especially because biomarkers are not always associated with meaningful benefits to the patients [25]. Until 2013, fewer than $30 \%$ of clinical studies for orphan drugs included QoL-related outcomes [26]. We reviewed the literature with three aims: (1) to identify patient and/or caregiver-reported HrQoL instruments - both generic and disease-specific - used among IMDs (2) to identify the main results of the application of each HrQoL tool and (3) to evaluate the main limitations of HrQoL instruments and study design/methodology in IMDs to guide future studies.

\section{Methods}

Data source and search strategy

Our scoping review strategy followed the methodological framework outlined by Arksey and O'Malley [27]. We searched the PubMed database with pre-defined search terms from inception until 26th February 2018. No other sources were included because we are a non-profit organization without external funding and, consequently, no access to databases that require subscription. Two groups of search terms (Additional file 1) were employed: 1) QoL related and 2) IMDs related terms. Free text terms were generated through a pilot PubMed search. We applied every combination of search terms from both groups connected by the Boolean operator "AND". Resulting articles from our search were exported to Mendeley Desktop and duplicated articles were eliminated. References of relevant articles were screened, and additional articles were included by author referral.

\section{Study selection and data extraction}

The review was conducted by two researchers. Inclusion criteria were as follows: studies had to be written in English and measure HrQoL using a PROM/ObsROM in an IMD context. Clinician reported outcomes, interviews and reviews were excluded, in order to focus on empirical research-generated evidence. Titles and abstracts were screened and studies that did not meet the criteria were excluded. The remaining article full-text versions were then read and included or excluded according to pre-defined criteria. Any disagreements were settled by discussion.

\section{Critical appraisal strategy}

The methodological quality of included studies was assessed using a checklist (Additional file 2) with criteria adapted from a published HrQoL assessment study [28]. The main limitations of the included studies were identified resorting to this checklist.

\section{Results}

The initial search of PubMed identified 1954 articles, 13 of which were duplicates. The title and abstract-based selection 
excluded 1744 articles. One hundred ninety-seven studies moved to the second round of selection. Based on the full-text review of each article, 91 were excluded and 108 were included. Reference screening or author referral led to the inclusion of 23 additional articles. Finally, 131 articles met the inclusion criteria. These were published between 1999 and 2017. The selection workflow is presented in Fig. 1.

\section{Generic and specific HrQoL instruments in IMDs pediatric} and adult populations

In total, we identified $32 \mathrm{HrQoL}$ assessment instruments used across IMDs (Table 1). While $84 \%$ of the manuscripts reported the use of only one $\mathrm{HrQoL}$ instrument, $13 \%$ applied two and another 3\% used three or more instruments. The 36-Item Short Form Health Survey (SF-36) was the most frequently used measure to evaluate HrQoL across IMDs, applied in 53\% of all included studies, followed by the EuroQoL- Five Dimension (EQ-5D) questionnaire (17\%). Concerning the pediatric population, the Pediatric Quality of Life Inventory (PedsQL) and the Child Heath Questionnaire (CHQ) were found to be the most utilized either as self- or proxy-reports, present in 12 and $8 \%$ of the studies, respectively. Of note, the total number of instruments applied to the pediatric population is similar to that of the adult population (17 and 15 tools, respectively). However, the number of studies designed to assess $\mathrm{HrQoL}$ in adults is far superior to the ones directed to children. Only $2 \%$ of the studies resorted to specific instruments. Remarkably, only one of these tools

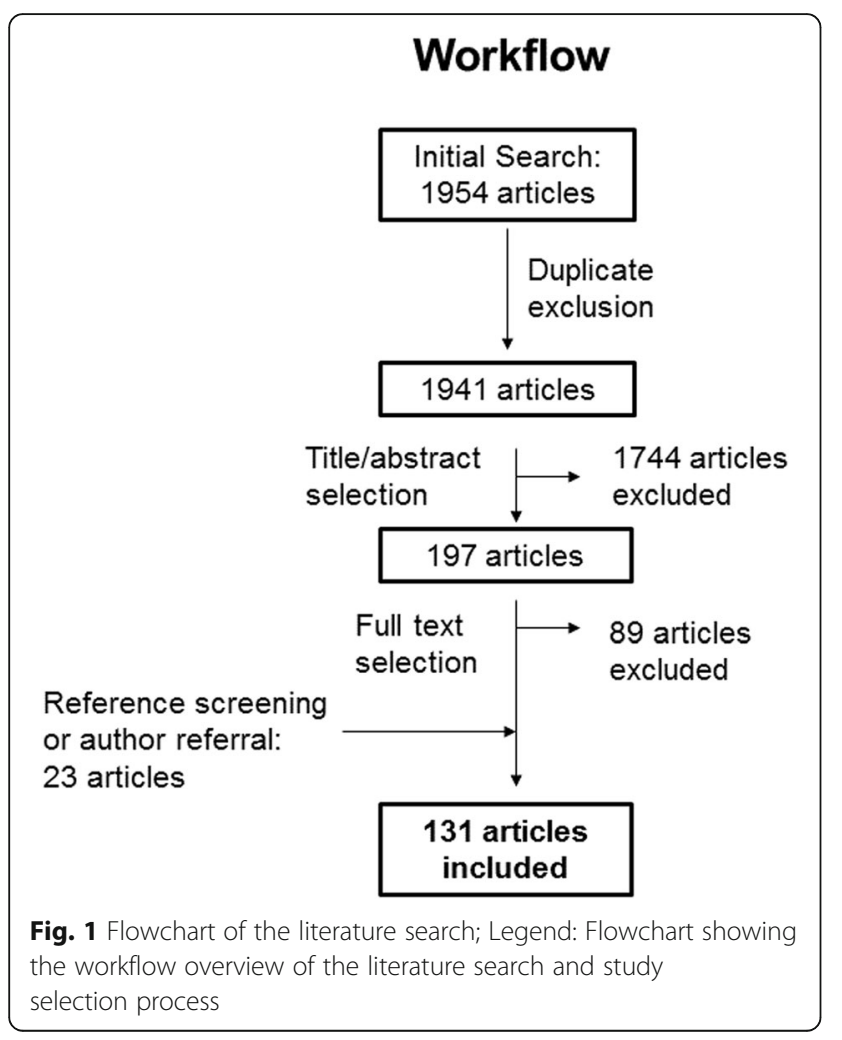

is specific for adults, whereas three target children. Among the IMDs in which HrQoL was assessed, only phenylketonuria (PKU) has disease-specific questionnaires, however, there are still studies that use generic instruments to evaluate HrQoL in PKU patients. Importantly, among the identified tools there is a broader instrument targeting metabolic diseases, namely the QoL Scale for Metabolic Diseases-Parent Form. This is a validated, author-built questionnaire specifically developed to evaluate the HrQoL of children with restrictive diets [24]. Despite clear efforts, only about $7 \%$ of the more than the 1000 identified IMDs have registered patient or observer-reported HrQoL assessments.

\section{Proxy-reports to complement self-reports}

Most metabolic disorders affect not only adults but also the pediatric population. Tools adjusted to obtain information on this population, such as PedsQL and CHQ, have been developed including proxy-versions. It is a common methodological assumption that self-reports are the best method for collecting information [29], because they are the vision of oneself. In contrast, proxy-reports tend to reflect the point of view of another. However, young age and/or disease impact raise the need for proxy-reports [6]. In fact, only $6 \%$ of the analysed manuscripts registered the sole use of proxy-reports [30-37].

A combined approach of both proxy- and self-reports to obtain HrQoL data was used in $21 \%$ of the studies. For $7 \%$ of the articles analysed, there were no differences between self- and parent-proxy data [30, 38-45]. Nevertheless, parent-reported HrQoL scores were lower than reports of children with Niemann-Pick disease, MPS VI, MSUD, other OAs and UCDs. [30, 46-51[ Only in one case, in contrast, higher QoL regarding the fatigue scale was reported by parents of type II citrullinemia patients when compared with the self-reports [51].

\section{HrQoL is generally impaired in IMDs}

A rising number of studies using self- and/or proxy reported PROMs or ObsROMs to evaluate the impact of IMDs in HrQoL has been registered. These include both observational studies and baseline measurements performed in interventional studies. The SF-36 questionnaire was the most frequently used (51\% of the studies), particularly in the adult population. This instrument revealed overall $\mathrm{HrQoL}$ impairment in a wide range of IMDs, including Fabry disease [52-59], Gaucher disease type I [60, 61], Pompe disease [62-65], mevalonate kinase deficiency [66], hereditary hemochromatosis [67], acute porphyrias [68], MELAS [69], McArdle disease [70], MPS [35, 71], Niemann-Pick type B [47], Niemann-Pick type C [72] and X-linked hypophosphatemia [73]. The EQ-5D (15\%) showed consistently low HrQoL scores in Fabry disease [52, 53, 74], Pompe disease [75], MPS [76, 77] and acute porphyrias [68]. Less frequently used tools, namely TAAQOL (6\%), SF-12 (4\%), PLC (4\%), SIP-136 (one study) and WHOQOL-BREF (one 
Table $1 \mathrm{HrQoL}$ instruments used across IMDs as PROMs or ObsROMs (Continued)

\begin{tabular}{|c|c|c|c|c|}
\hline $\begin{array}{l}\text { Instrument } \\
\text { Name }\end{array}$ & Sub-scales & $\begin{array}{l}\text { Item } \\
\text { number }\end{array}$ & Target Group (years) & IMDs \\
\hline WHOQOL-100 & $\begin{array}{l}\text { Vitality, psychological well-being, relationship } \\
\text { with friends, leisure activities, relationship with } \\
\text { parents, physical well-being, relationship with } \\
\text { teachers, school, body image, relationship with } \\
\text { medical staff. }\end{array}$ & 100 & $>18$ & IMDs [125], PKU [43] \\
\hline $\begin{array}{l}\text { WHOQOL- } \\
\text { BREF }\end{array}$ & $\begin{array}{l}\text { Physical health, psychological health, social } \\
\text { relationships, and environment }\end{array}$ & 26 & $>18$ & $\begin{array}{l}\text { Pompe disease [126], OAs, including MMA, PA, } \\
\text { IVA and GA1; and UCDs, including CPS1 } \\
\text { deficiency, citrullinemia type I, ASL deficiency, } \\
\text { HHH syndrome and OTC deficiency [50], } \\
\text { oculocutaneous albinism [81], Wilson disease } \\
\text { [171] }\end{array}$ \\
\hline
\end{tabular}

Specific

PKU-OOL Adult version

PKU symptoms, PKU in general (emotional, 65 $>18$ PKU [89] (pocial and overall impact), administration of Phe-free protein supplements, dietary protein restriction

Pediatric instruments

General

$\mathrm{CHQ}$

General health, physical functioning, role limitations due to emotional problems, role limitations due to physical health, body pain,

CHQ-CF87 behaviour, global behaviour, mental health,

CHQ-PF28 self-esteem, general health perceptions, emotional parental impact, time parental impact,

CHQ-PF50 family activities, family cohesion.

DISABKIDS-37 Independence, emotion, inclusion, exclusion, limitations, treatment

HUI 2 Sensation, mobility, emotion, cognition, selfcare, pain, fertility

HUI 3

Vision, hearing, speech, ambulation, dexterity, emotion, cognition, pain

KIDSCREEN-27 Walking/standing, Reach/grip, Sleeping, School/ work, Activities and Breathing; and a satisfactionwith-function and a botheredness-with-function domains

KINDL

Physical well-being, psychological well-being, autonomy and parents, peers \& social support, school environment

KiddyKINDL

KidKINDL

KiddoKINDL

PedsQL
Physical, emotional, social and school functioning

\section{$5-18$ \\ Familial hypomagnesemia [85], MPS IH [36], MPS II [37]}

$87 \quad 5-18$

$5-18$

$5-18$

$37 \quad$ Children and adolescents with chronic diseases

15 (self) $>5$

15 (self) $>5$

$27 \quad 8-18$

$4-16$

12: self $\quad 4-6$ or their parents 46: proxy

$\begin{array}{ll}24 & 7-13 \text { or their parents } \\ 24 & 14-17 \text { or their parents } \\ 23 & 5-18\end{array}$

Fabry disease [82], MPS II [42]

PKU [89]

Fabry disease [40, 82], MPS II [42], NiemannPick type B [47], PKU [166]

PKU [46]

Fabry disease [40]

Fabry disease [40], MPS II [42]

MPS II [77]

PKU $[44,45]$, carbohydrate metabolism disorders including GSD, galactosemia, and fructose-1,6bisphosphatase deficiency; OAs including MMA, PA, MSUD, 3-methylcrotonyl CoA carboxylase deficiency and 3-hydroxy-2-methylglutaryl CoA lyase deficiency; and amino acid metabolism disorders including PKU, alkaptonuria, homocystinuria and tyrosinemia [24]

Propionic acidemia [97]

PKU $[43,46,50,84,89]$, OAs, including MMA, PA, IVA, GA1; UCDs, including CPS1 deficiency, citrullinemia type I, ASL deficiency, HHH syndrome and OTC deficiency [50], citrin deficiency [51], MPS [35], GSD type I [39], MSUD [48], nephropathic cystinosis [123], Fabry disease [83] 
Table $1 \mathrm{HrQoL}$ instruments used across IMDs as PROMs or ObsROMs (Continued)

\begin{tabular}{|c|c|c|c|c|}
\hline $\begin{array}{l}\text { Instrument } \\
\text { Name }\end{array}$ & Sub-scales & $\begin{array}{l}\text { Item } \\
\text { number }\end{array}$ & Target Group (years) & IMDs \\
\hline $\begin{array}{l}\text { PedsQL parent } \\
\text { version }\end{array}$ & & 23 & $\begin{array}{l}\text { Parents of } 2-18 \text { years old } \\
\text { patients }\end{array}$ & $\begin{array}{l}\text { Batten disease [31], citrin deficiency [51], Fabry } \\
\text { disease [83], GSD type I [39], MMA [34], MPS [35], } \\
\text { MSUD [48], PKU [43, 46, 84], OAs, including MMA, } \\
\text { PA, IVA, GA1; UCDs, including CPS1 deficiency, } \\
\text { citrullinemia type I, ASL deficiency, HHH } \\
\text { syndrome, OTC deficiency [50] and inborn errors } \\
\text { of metabolism in general [33] }\end{array}$ \\
\hline PODCl & $\begin{array}{l}\text { Upper extremity function, transfers and } \\
\text { mobility, physical function and sports, comfort } \\
\text { (lack of pain), happiness, satisfaction, and } \\
\text { expectations }\end{array}$ & 42 & $2-18$ & MPS IVa [115] \\
\hline SF-10 & $\begin{array}{l}\text { Physical functioning, role-physical, bodily pain, } \\
\text { general health perceptions, vitality, social func- } \\
\text { tioning, role emotional and mental health }\end{array}$ & 10 & 5-18 children's parents & LC-FAOD [38] \\
\hline TACQOL & $\begin{array}{l}\text { General physical functioning, motor } \\
\text { functioning, autonomy, cognition, social } \\
\text { contacts, positive mood, negative mood }\end{array}$ & 56 & $\begin{array}{l}6-11 \text { or their parents (parent } \\
\text { form) }\end{array}$ & $\begin{array}{l}\text { Cystinosis [86], familial hypercholesterolemia } \\
\text { [96], galactosemia [89], PKU [30], MPS VI [49] }\end{array}$ \\
\hline TAPQOL & $\begin{array}{l}\text { Stomach problems, skin problems, lung } \\
\text { problems, sleeping problems, appetite, } \\
\text { problem behaviour, positive mood, anxiety, } \\
\text { liveliness, social functioning*, motor } \\
\text { functioning* and communication* }\end{array}$ & 43 & $\begin{array}{l}\text { Parents of } 9 \text { months- } 6 \text { years } \\
\text { children }\end{array}$ & $\begin{array}{l}\text { Galactosemia [89] } \\
\text { MPS VI [49] }\end{array}$ \\
\hline VSP-Ae & $\begin{array}{l}\text { Gross motor functioning, fine motor } \\
\text { functioning, cognition, sleep, pain, social } \\
\text { contacts, daily activities, sex, vitality, happiness, } \\
\text { depressive mood, anger }\end{array}$ & 38 & $8-10$ & OAs, UCDs, MSUD [41] \\
\hline VSP-A & $\begin{array}{l}\text { Physical functioning, motor functioning, } \\
\text { autonomy, cognitive functioning, social } \\
\text { functioning, positive and negative emotional } \\
\text { functioning }\end{array}$ & 39 & $11-17$ & OAs, UCDs, MSUD [41] \\
\hline VSP-Ap & $\begin{array}{l}\text { Symptoms, sleeping, appetite, motor } \\
\text { functioning, behaviour, social functioning, } \\
\text { communication, positive and negative } \\
\text { emotional functioning }\end{array}$ & 37 & Parents of patients of all ages & OAs, UCDs, MSUD [41] \\
\hline \multicolumn{5}{|l|}{ Specific } \\
\hline PKU-QOL & \multirow{4}{*}{$\begin{array}{l}\text { PKU symptoms, PKU in general (emotional, } \\
\text { practical, social and overall impact), } \\
\text { administration of Phe-free protein supple- } \\
\text { ments, dietary protein restriction }\end{array}$} & & & PKU [89] \\
\hline Child & & 40 & $9-11$ & \\
\hline Adolescent & & 58 & $12-17$ & \\
\hline Parent & & 54 & PKU patients' parents & \\
\hline PKU-QOLQ & $\begin{array}{l}\text { Impact, worries, satisfaction, support, well- } \\
\text { being }\end{array}$ & NA & $10-18$ & PKU [124] \\
\hline $\begin{array}{l}\text { QoL Scale for } \\
\text { Metabolic } \\
\text { Diseases - } \\
\text { Parent Form }\end{array}$ & $\begin{array}{l}\text { Impact of disease, attention, perception of disease, } \\
\text { physical function, stigmatization, social support, } \\
\text { school status, and health perception }\end{array}$ & 28 & $\begin{array}{l}\text { Parents of children }(1-15) \\
\text { with a metabolic disorder } \\
\text { treated with restrictive diet } \\
\text { for at least } 1 \text { year }\end{array}$ & $\begin{array}{l}\text { Carbohydrate metabolism disorders, } \\
\text { including GSD, galactosemia, fructose-1,6- } \\
\text { bisphosphatase deficiency; OA including } \\
\text { MMA, PA, MSUD, 3- methylcrotonyl CoA } \\
\text { carboxylase deficiency, 3-hydroxy-2-methyl- } \\
\text { glutaryl CoA lyase deficiency; amino acid } \\
\text { metabolism disorders including PKU, alkapto- } \\
\text { nuria, homocystinuria, tyrosinemia [24] }\end{array}$ \\
\hline
\end{tabular}

HrQoL tools were divided into 2 main categories: adult-oriented and pediatric instruments. They were then further classified into general and disease-specific tools. Abbreviations: AQOL-4D Assessment of Quality of Life 4D, ASL Argininosuccinate lyase, CHQ Child Health Questionnaire, CPS1 Carbamylphosphate synthase 1, GA1 Glutaric aciduria type I, GSD Glycogen storage disease, HHH Hyperammonemia-hyperomithinemiahomocitrullinuria, HUI Health Utilities Index, MELAS Mitochondrial encephalomyopathy, lactic acidosis, and stroke-like episode, LC-FAOD Long-chain fatty acid oxidation disorders, MMA Methylmalonic acidemia, IVA Isovaleric acidemia, MPS Mucopolysaccharidosis, MSUD Maple syrup urine disease, NHP Nottingham Health Profile, OAs Organic acidurias, OTC Ornithine transcarbamylase, PA Propionic acidemia, PedsQL Pediatric Quality of Life inventory, PGWBI Psychological General Well-Being Index, PLC Profile for the Chronically ill, PKU-OOL Phenylketonuria-Quality of Life, SIP Sickness Impact Profile, SF-36 36-Item Short Form survey, TAAQOL TNO-AZL questionnaire for adult's HrQoL, TACQOL TNO-AZL questionnaire for children's HrQoL, TAPQOL TNOAZL questionnaire for preschool children's HrQoL, UCDs Urea cycle disorders, VAS Visual analogue scale, VSP-A Vécu et Santé Percue de l'Adolescent, WHOQOL World Health Organization Quality of Life *Only for children older than 18 months 
study), detected reduced $\mathrm{HrQoL}$ in galactosemia (only at the mental level) [78, 79], hypophosphatasia [80], MELAS [69] and oculocutaneous albinism (only at the physical level) [81].

Regarding instruments applied to the pediatric population, the PedsQL and the CHQ were administered in 11 and $9 \%$ of the studies, respectively. They described compromised HrQoL in Fabry disease [82, 83], MPS [35, 37, 42], PKU [84], Niemann-Pick type B [47], familial hypomagnesaemia [85], MSUD [48], methylmalonic acidemia [34] and GSD type I [39]. The TACQOL (8\%) and TAPQOL (4\%) detected low HrQoL in cystinosis [86], galactosemia [78], MPS VI [49] and PKU (only at the emotional level) [30]. Two other tools were administered in MPS II, in one study each, namely the HUI 3 and KIDSCREEN-27, revealing a negative impact of this disease on HrQoL [42, 77].

The detrimental effect of IMDs on patients' HrQoL is mainly attributed to disease severity and associated complications, but also to its emotional and financial burden. We found several parameters and comorbidities associated with impaired $\mathrm{HrQoL}$, namely, age, kidney and respiratory function, pain, overweight, the burden of a restrictive diet as well as gastrointestinal, cardiovascular, skeletal and neurologic involvement $[52,57,58,60,61$, 63, 74, 76-79, 87-92].

In a set of cases, the employment of HrQoL instruments did not show substantial impairments compared to control populations. Specifically, the administration of SF-36, PLC, TAAQOL, WHOQOL-100 and KINDL (the last used in $4 \%$ of the studies) found normal HrQoL scores in PKU patients [30, 43, 45, 93, 94]. Also, in familial hypercholesterolemia patients, SF-12, TACQOL and 15D (applied in one study) did not show differences in HrQoL compared to healthy peers $[91,95,96]$. No differences in HrQoL were found in patients with mevalonate kinase deficiency when the cognition scale of TAAQOL was administered alone. Importantly, KINDL application in propionic acidemia revealed normal $\mathrm{HrQoL}$ scores despite poor neurological and psychosocial outcomes [97].

\section{HrQoL tools detect changes upon treatment in IMD}

Besides clinical parameters and disease-specific biomarkers, HrQoL is now recognized as an essential instrument to determine therapeutic effects. Multiple studies included the assessment of changes in HrQoL upon treatment initiation to better evaluate the therapeutic benefits (Table 2). The SF-36 was predominantly utilized ( $67 \%$ of the interventional studies). Generally, this tool was capable of detecting alterations in $\mathrm{HrQoL}$ scores across several IMDs [60, 64, 98-114], with the exception of MPS IV and Wilson disease $[115,116]$. Interestingly, whilst no changes were observed using SF-36 in late-onset Pompe disease, NHP was responsive in this patient niche [117-119]. Regarding EQ-5D, detectable variations were observed in Fabry disease patients [120-122]. However, HUI and CHQ administration in Fabry disease children did not perceive deviations in HrQoL [40]. Changes in HrQoL were captured by SF-12 in
LC-FAOD. On the other hand, in this pediatric population, administration of parent-reported SF-10 did not reveal any differences [38]. In MPS IV, PODCI only detected differences in 1 out of 4 children [115]. PedsQL was able to find fluctuations in HrQoL of Fabry disease and nephropathic cystinosis patients [83, 123]. In MPS VI, the application of TAPQOL/TACQOL also detected modifications in HrQoL [49]. When HrQoL was measured using general instruments, namely TAAQOL, KINDL and PedsQL in PKU, $\mathrm{BH}_{4}$ responsive patients' HrQoL did not differ from non-responsive ones 24 months after treatment initiation $[44,46]$. In contrast, HrQoL assessment with the specific PKU-QOLQ instrument detected a significant improvement in the responsive patients' life quality for up to 1 year [124].

Attesting the importance of HrQoL PROMs and ObsROMs instruments, the continuous increase of $\mathrm{HrQoL}$ assessment reports in IMDs is accompanied by an increase in the number of approved therapies for these disorders (Fig. 2).

\section{Critical appraisal and main limitations of HrQoL studies}

We critically assessed the quality of the included studies and identified some concerns due to an increased risk of bias (see Additional file 2). Although most studies used a standardized generic tool, validation is rarely obtained for the population in which the instrument is being used. Therefore, the results of the use of a non-specifically validated tool for a certain population should be interpreted with caution. Mostly, the problems faced by clinical researchers dealing with IMDs are inherent to the rarity of these conditions. The biggest limitation is the small sample size $[34,37,41,53,56,65,77,82,85,100,102,105,112$, $115,125-130]$. This makes it difficult to reach statistically significant conclusions $[35,39,43,44,46,75,79,83,86,90$, 93, 99, 131-133] and also precludes the use of adequate control samples as placebo-control groups $[40,58,70,76$, $103,108,109,119,121,134,135]$. To counteract the problem of small samples, multinational studies are being performed. However, this can raise other limitations, particularly cross-cultural differences $[42,70,89]$ as well as variations in the range of investigations, protocol and rigor between centres [92, 121]. Still, pooling data from multinational studies might be adequate if the study design, the methods, linguistic and cognitive equivalence of the concepts being measured are achieved [136]. Thus, validation should be a never-ending process and one should always look for the psychometric and cross-cultural validity, reliability and acceptability of the measure in the context of each study. Nevertheless, small sample sizes might be considered representative due to the rarity of the condition and the study objectives [39, 52, 55, 78, 89, 95]. Some countries may not have normative data available and comparison of results with foreign data or with other chronic conditions may be a source of bias $[52,54,70,83,128,131]$. Moreover, 55\% manuscripts do not justify the selection of the HrQoL 
Table 2 PROMs/ObsROMs HrQoL instruments used across IMDs to evaluate therapeutic benefit in clinical studies

\begin{tabular}{|c|c|c|c|c|c|c|}
\hline $\mathrm{IMD}$ & Sample (age in years) & $\begin{array}{l}\text { Treatment/ } \\
\text { Therapy }\end{array}$ & $\begin{array}{l}\text { Follow } \\
\text { up time }\end{array}$ & $\begin{array}{l}\text { HrQoL } \\
\text { tool }\end{array}$ & Effects on HrQoL and major findings & Ref. \\
\hline \multirow{2}{*}{$\begin{array}{l}\text { Carnitine palmitoyl } \\
\text { transferase II } \\
\text { deficiency }\end{array}$} & Adults & Bezafibrate & $\begin{array}{l}6 \\
\text { months }\end{array}$ & SF-36 & $\begin{array}{l}\text { - } \uparrow \text { HrQoL in all domains, specially role limitations } \\
\text { due to physical health and body pain }\end{array}$ & {$[158]$} \\
\hline & Children and adults (10-55) & $\begin{array}{l}\text { Anaplerotic } \\
\text { diet therapy }\end{array}$ & $\begin{array}{l}\text { 7-61 } \\
\text { months }\end{array}$ & SF-36 & - $\uparrow$ HrQoL in the physical component score & {$[106]$} \\
\hline \multirow[t]{14}{*}{ Fabry disease } & Male adults (16-48) & Agalsidase- $\beta$ & $\begin{array}{l}10 \text { days- } \\
20 \\
\text { weeks }\end{array}$ & SF-36 & $\begin{array}{l}\text { - Phase } 1 / 2 \text { trial that proved the efficiency and } \\
\text { safety of Fabrazyme including an } \uparrow \mathrm{HrQoL} \text {, } \\
\text { namely regarding bodily pain, general health, } \\
\text { vitality, physical role and emotional role } \\
\text { domains. Placebo effects were noticed. }\end{array}$ & $\begin{array}{l}{[107} \\
108]\end{array}$ \\
\hline & Adults and adolescents (> 14) & Agalsidase- $\beta$ & 3 years & SF-36 & - $\uparrow \mathrm{HrQoL}$ more pronounced in men & [109] \\
\hline & Adults (41.4, mean) & Agalsidase- $\beta$ & 2 years & SF-36 & - Ns changes in HrQoL & {$[141]$} \\
\hline & Male adults (16-34) & Agalsidase- $\beta$ & $\begin{array}{l}20 \\
\text { weeks }\end{array}$ & SF-36 & $\begin{array}{l}\text { - } \uparrow \text { HrQoL with significant changes in the general } \\
\text { health and the mental component score }\end{array}$ & {$[110]$} \\
\hline & Adults & Agalsidade- $a$ & 2 years & EQ-5D & - Significant $\uparrow \mathrm{HrQoL}$ & {$[120]$} \\
\hline & Adults & Agalsidase- $a$ & 2 years & EQ-5D & $\begin{array}{l}\text { - Significant } \uparrow \text { HrQoL which negatively } \\
\text { correlates with pain }\end{array}$ & [122] \\
\hline & Adults $(39.2 \pm 12.3$, mean $)$ & Agalsidase- $a$ & 5 years & EuroQoL & - Significant $\uparrow \mathrm{HrQoL}$ & {$[121]$} \\
\hline & $\begin{array}{l}\text { Adults (males: } 44.25 \pm 11 \\
\text { females: } 52.3 \pm 10.5, \text { means) }\end{array}$ & Agalsidase- $a$ & 4 weeks & EQ-5D & $\begin{array}{l}\text { - Ns differences in HrQoL in the } 3 \text { dose } \\
\text { regimens. (NCT01218659) }\end{array}$ & [129] \\
\hline & Heterozygous females (20-66) & Agalsidase- $a$ & $\begin{array}{l}55 \\
\text { weeks }\end{array}$ & SF-36 & $\begin{array}{l}\text { - Phase } 3 \text { study that proved the agalsidase-a safety } \\
\text { and efficacy in heterozygous females with signifi- } \\
\text { cant } \uparrow \mathrm{HrQoL} \text {, mostly in the physical domain. }\end{array}$ & {$[111]$} \\
\hline & Children (7-18) & Agalsidase-a & $\begin{array}{l}55 \\
\text { weeks }\end{array}$ & $\mathrm{HUI}, \mathrm{CHQ}$ & $\begin{array}{l}\text { - Phase } 2 \text { study that showed the efficiency and } \\
\text { safety of agalsidase-a, however HrQoL } \\
\text { remained unchanged. (NCT01363492) }\end{array}$ & {$[40]$} \\
\hline & Adults $(42.5 \pm 12.5$, mean $)$ & ERT & $\begin{array}{l}6.1 \pm 2.5 \\
\text { years }\end{array}$ & EQ-5D & $\begin{array}{l}\text { - } \uparrow \mathrm{HrQoL} \text { in severely affected males } \\
\text { - Unchanged HrQoL in women } \\
\text { - Annual } \downarrow \text { in HrQol in non-classical patients }\end{array}$ & [74] \\
\hline & Adults (26-68) & ERT & $\begin{array}{l}4-7 \\
\text { years }\end{array}$ & SF-36 & $\begin{array}{l}\text { - Stable HrQoL except for the social functioning } \\
\text { score. }\end{array}$ & {$[161]$} \\
\hline & Children (6-18) & ERT & - & PedsQL & $\begin{array}{l}\text { - Children on ERT had higher scores that } \\
\text { approached significance. }\end{array}$ & {$[83]$} \\
\hline & Adults (16-74) & Migalastat & 2 years & SF-36 & $\begin{array}{l}\text { - Results did not reveal any clinical benefit } \\
\text { (NCT00925301 and NCT01458119) }\end{array}$ & {$[162]$} \\
\hline $\begin{array}{l}\text { Familial } \\
\text { hypercholesterolemia }\end{array}$ & Children and adults (9-57) & LDL apheresis & NA & SF-36 & - $\uparrow \mathrm{HrQoL}$ in 2 patients with baseline data & {$[112]$} \\
\hline \multirow[t]{6}{*}{$\begin{array}{l}\text { Gaucher disease type } \\
\text { I }\end{array}$} & Children and adults (12-70) & Imiglucerase & 4 years & SF-36 & $\begin{array}{l}\text { - Significant } \uparrow \mathrm{HrQoL} \text { in the physical } \\
\text { component score and, particularly, the } \\
\text { physical functioning, physical role limitations } \\
\text { and bodily pain subscores. (NCT00365131) }\end{array}$ & {$[60]$} \\
\hline & Adults (18-82) & Imiglucerase & 2 years & SF-36 & $\begin{array}{l}\text { - Since baseline HrQoL approached those of the } \\
\text { general population, there was no space for } \\
\text { improvements and ns changes were observed. }\end{array}$ & {$[164]$} \\
\hline & Adults (17-69) & Miglustat & $\begin{array}{l}6-24 \\
\text { months }\end{array}$ & SF-36 & $\begin{array}{l}\text { - Miglustat administration significantly } \uparrow \mathrm{HrQoL}, \\
\text { while imiglucerase or combination of both } \\
\text { reduced HrQoL }\end{array}$ & [113] \\
\hline & $\begin{array}{l}\text { Adults }(35.2 \pm 10.2 \text {, mean at } \\
\text { start) }\end{array}$ & Miglustat & $\begin{array}{l}12-48 \\
\text { months }\end{array}$ & SF-36 & $\begin{array}{l}\text { - Similar improvements in HrQoL between } \\
\text { miglustat and ERT-treated patients. }\end{array}$ & [114] \\
\hline & Adults (18-66) & ERT & 2 years & SF-36 & $\begin{array}{l}\text { - Self-perception of global health, physical activ- } \\
\text { ity and social functioning improved with ERT. }\end{array}$ & [61] \\
\hline & Children and adults (>5) & ERT or SRT & $\begin{array}{l}10 \text { years } \\
\text { (mean) }\end{array}$ & SF-36 & $\begin{array}{l}\text { - } 65 \text { patients achieved the therapeutic goal for } \\
\text { HrQoL but differences between treated and } \\
\text { untreated patients were ns. }\end{array}$ & [99] \\
\hline
\end{tabular}


Table 2 PROMs/ObsROMs HrQoL instruments used across IMDs to evaluate therapeutic benefit in clinical studies (Continued)

\begin{tabular}{|c|c|c|c|c|c|c|}
\hline $\mathrm{IMD}$ & Sample (age in years) & $\begin{array}{l}\text { Treatment/ } \\
\text { Therapy }\end{array}$ & $\begin{array}{l}\text { Follow } \\
\text { up time }\end{array}$ & $\begin{array}{l}\text { HrQoL } \\
\text { tool }\end{array}$ & Effects on HrQoL and major findings & Ref. \\
\hline & $\begin{array}{l}\text { Children and adults ( }>12 \text { ) } \\
\text { (one type } 3 \text { Gaucher disease } \\
\text { patient) }\end{array}$ & ERT & $\begin{array}{l}8.5 \text { years } \\
\text { (mean) }\end{array}$ & SF-36 & $\begin{array}{l}\text { - Bodily pain was significantly decreased in ERT- } \\
\text { naïve patients but physical functioning, role } \\
\text { physical, general health, social functioning and } \\
\text { role emotional scores showed clinical meaning- } \\
\text { ful impairments too. } \\
\text { - Gaucher disease patients receiving ERT have } \\
\text { significant higher scores than Fabry disease } \\
\text { patients also receiving ERT. }\end{array}$ & [128] \\
\hline $\begin{array}{l}\text { Hereditary } \\
\text { hemochromatosis }\end{array}$ & Adults (55 \pm 9.0 , mean) & $\begin{array}{l}\text { Erythrocytaphe- } \\
\text { resis }\end{array}$ & 2 years & SF-36 & $\begin{array}{l}\text { - There is no benefit in terms of HrQoL of } \\
\text { erythrocytapheresis over phlebotomy. } \\
\text { (NCT01398644) }\end{array}$ & [155] \\
\hline MPS IH & Children and adults (2-25) & $\begin{array}{l}\text { Hematopoietic } \\
\text { cell transplant }\end{array}$ & $\begin{array}{l}9 \text { years } \\
\text { (mean) }\end{array}$ & $\begin{array}{l}\text { CHQ- } \\
\text { PF50 }\end{array}$ & $\begin{array}{l}\text { - Higher age at transplant correlates with poor } \\
\text { physical scores }\end{array}$ & {$[36]$} \\
\hline LC-FAOD & $\begin{array}{l}\text { Children and adults }(12.06 \pm \\
13.2, \text { mean) }\end{array}$ & $\begin{array}{l}\text { Triheptanoin } \\
\text { (UX007) }\end{array}$ & $\begin{array}{l}24 \\
\text { weeks }\end{array}$ & $\begin{array}{l}\text { SF-12, } \\
\text { SF-10 }\end{array}$ & $\begin{array}{l}\text { - Significant } \uparrow \mathrm{HrQoL} \text { in the physical and } \\
\text { mental domains for adults but not for } \\
\text { children. (NCT01886378) }\end{array}$ & {$[38]$} \\
\hline MPS VI & Children and adults (5-21) & Arylsulfatase B & $\begin{array}{l}1.3-5-4 \\
\text { years }\end{array}$ & $\begin{array}{l}\text { TAPQOL, } \\
\text { TACQOL }\end{array}$ & $\begin{array}{l}\text { - } \uparrow \text { HrQoL regarding lung problems, sleeping, } \\
\text { liveliness, positive mood, social functioning } \\
\text { and communication } \\
\text { - } \downarrow \text { HRQoL in the anxiety and negative emotions } \\
\text { domains }\end{array}$ & {$[49]$} \\
\hline McArdle's disease & Adults (18-60) & Ramipril & $\begin{array}{l}3 \\
\text { months }\end{array}$ & SF-36 & $\begin{array}{l}-\uparrow \mathrm{HrQoL} \text { in the emotional status and social role } \\
\text { in both ramipril and placebo groups }\end{array}$ & $\begin{array}{l}{[100,} \\
101]\end{array}$ \\
\hline MPS IV & Children and adults (9.8-42.2) & Elosulfase- $a$ & $\begin{array}{l}48-96 \\
\text { weeks }\end{array}$ & $\begin{array}{l}\text { SF-36, } \\
\text { PODCI }\end{array}$ & $\begin{array}{l}\text { - Stable HrQoL, except in } 1 \text { child with } \downarrow \text { HrQoL } \\
\text { (NCT01697319) }\end{array}$ & [115] \\
\hline $\begin{array}{l}\text { Nephropathic } \\
\text { cystinosis }\end{array}$ & $\begin{array}{l}\text { Children and adolescents (6- } \\
\text { 21) }\end{array}$ & $\begin{array}{l}\text { Delayed-release } \\
\text { cysteamine } \\
\text { birtrate }\end{array}$ & 2 years & PedsQL & $\begin{array}{l}\text { - Significant } \uparrow \text { HrQoL particularly in social, } \\
\text { school and total function. }\end{array}$ & [123] \\
\hline \multirow[t]{8}{*}{ Pompe disease } & Adults (41-42) & Alglucosidase- $a$ & 2 years & SF-36 & $\begin{array}{l}\text { - } \uparrow \text { HrQoL, particularly in the bodily pain } \\
\text { domain }\end{array}$ & [102] \\
\hline & Adults (28-62) & Alglucosidase- $a$ & $\begin{array}{l}52 \\
\text { weeks }\end{array}$ & SF-36 & $\begin{array}{l}\text { - } 3 / 5 \text { patients improved both physical and } \\
\text { mental scores while } 1 / 5 \text { improved only the } \\
\text { mental or the physical score }\end{array}$ & [103] \\
\hline & Late onset adults (27-73) & Alglucosidase- $a$ & $\begin{array}{l}36 \\
\text { months }\end{array}$ & SF-36 & - Ns differences from baseline & [117] \\
\hline & Late onset adults (21-69) & Alglucosidase- $a$ & 1 year & SF-36 & - Ns differences from baseline & [118] \\
\hline & Adults (24-76, at start) & ERT & $\begin{array}{l}4 \text { years } \\
\text { (median) }\end{array}$ & SF-36 & $\begin{array}{l}\text { - Significant } \uparrow \text { HrQoL in the physical } \\
\text { functioning, role physical, general health, } \\
\text { vitality and mental health subscores, after } 2 \\
\text { years. After } 4 \text { years, the bodily pain domain } \\
\text { significantly worsened. }\end{array}$ & {$[64]$} \\
\hline & Adult (65) & L-alanine & $\begin{array}{l}6 \\
\text { months }\end{array}$ & SF-36 & $\begin{array}{l}\text { - } \downarrow \text { HrQoL, mainly the physical domain due to } \\
\text { worsening of muscle function. } \uparrow \mathrm{HrQoL} \text { during } \\
\text { placebo interval reflecting the optimism of } \\
\text { entering a trial. }\end{array}$ & [104] \\
\hline & Adults (20-71) & $\begin{array}{l}\text { Exercise } \\
\text { program }\end{array}$ & $\begin{array}{l}12 \\
\text { weeks }\end{array}$ & SF-36 & - Borderline $\uparrow \mathrm{HrQoL}$ at the mental component & [105] \\
\hline & Late onset adults (35.5-60.7) & $\begin{array}{l}\text { Inspiratory } \\
\text { muscle training } \\
\text { program }\end{array}$ & 8 weeks & NHP & $\begin{array}{l}\text { - Significant } \uparrow \mathrm{HrQoL} \text { exclusively in the social } \\
\text { isolation subscore }\end{array}$ & [119] \\
\hline \multirow[t]{3}{*}{ PKU } & Children and adults (4-44) & $\mathrm{BH} 4$ & 1 year & $\begin{array}{l}\text { PedsQL, } \\
\text { TAAQOL }\end{array}$ & $\begin{array}{l}\text { - Unchanged HrQoL and similar between } \\
\text { responsive and non-responsive patients }\end{array}$ & {$[46]$} \\
\hline & $\begin{array}{l}\text { Children and adolescents } \\
(6.6-18.7)\end{array}$ & $\mathrm{BH} 4$ & $\begin{array}{l}6 \\
\text { months }\end{array}$ & KINDL & $\begin{array}{l}\text { - Unchanged HrQoL and similar between } \\
\text { responsive and non-responsive patients }\end{array}$ & {$[44]$} \\
\hline & Children and adults (10-49) & $\mathrm{BH} 4$ & 1 year & $\begin{array}{l}\text { PKU- } \\
\text { QOLQ }\end{array}$ & $\begin{array}{l}\text { - } \uparrow \text { HrQoL in responders, provisional responders } \\
\text { and non-responders in terms of impact, } \\
\text { satisfaction }\end{array}$ & [124] \\
\hline
\end{tabular}


Table 2 PROMs/ObsROMs HrQoL instruments used across IMDs to evaluate therapeutic benefit in clinical studies (Continued)

\begin{tabular}{|c|c|c|c|c|c|c|}
\hline $\mathrm{IMD}$ & Sample (age in years) & $\begin{array}{l}\text { Treatment/ } \\
\text { Therapy }\end{array}$ & $\begin{array}{l}\text { Follow } \\
\text { up time }\end{array}$ & $\begin{array}{l}\text { HrQoL } \\
\text { tool }\end{array}$ & Effects on HrQoL and major findings & Ref. \\
\hline \multirow[t]{2}{*}{ Wilson disease } & Children and adults (8-41) & $\begin{array}{l}\text { Orthotopic liver } \\
\text { transplantation }\end{array}$ & $\begin{array}{l}97 \\
\text { months } \\
\text { (mean) }\end{array}$ & SF-36 & $\begin{array}{l}\text { - Ns difference between norm-based scores } \\
\text { and patients who underwent transplantation }\end{array}$ & [116] \\
\hline & Adults $(36.6 \pm 12.9)$ & $\begin{array}{l}\text { D- } \\
\text { penicillamine, } \\
\text { trientine, zinc }\end{array}$ & $\begin{array}{l}8.1-12.6 \\
\text { years } \\
\text { (mean) }\end{array}$ & SF-36 & $\begin{array}{l}\text { - D-penicillamine-treated patients had the highest } \\
\text { HrQoL scores compared to trientine- or zinc- } \\
\text { treated patients. }\end{array}$ & [140] \\
\hline
\end{tabular}

Abbreviations: AQOL-4D Assessment of Quality of Life 4D, CHQ Child Health Questionnaire, HUI Health Utilities Index, LDL Low-density lipoprotein, NA non available, NHP Nottingham Health Profile, Ns No significant, PedsQL Pediatric Quality of Life Inventory, PGWBI Psychological General Well-Being Index, PLC Profile for the Chronically III, PODCI Pediatric Outcomes Data Collection Instrument, PKU-QOL Phenylketonuria-Quality of Life, SF-36 36-Item Short Form Survey, TAAQOL TNO-AZL questionnaire for Adult's HrQoL, TACQOL TNO-AZL Questionnaire for Children's HrQoL, TAPQOL TNOAZL Questionnaire for Preschool Children's HrQoL, VSP-A Vécu et Santé Percue de l'Adolescent, WHOQOL World Health Organization Quality of Life

instrument used. Since a variety of general instruments are available, this selection process should be clearly defined. Additionally, some answer option systems might not be capable of detecting small changes in health (i.e. EQ-5D) [74].

Some HrQoL studies are performed to assess the effects of a certain therapy. Consequently, they are administered before and after the therapy to provide baseline data and to register any possible improvement, respectively. In these cases, loss to follow-up due to noncompliance or abandonment is a recurrent issue [46]. Furthermore, missing data decreases the statistical validity/power of the study. Imputation of missing values can be made by researchers, but this is not always possible [137]. Finally, unreported clinical history and/or genotype data impair possible correlations with HrQoL scores [83].

Disease heterogeneity is very common to IMDs [31, 40, $75,89,99,103,115]$. On the one hand, in cross-sectional studies severe forms of a disease can counterbalance the higher HrQoL scores reached by patients with less severe presentations and vice-versa [43, 61, 71, 87, 138]. On the other hand, in order to avoid erroneous conclusions drawn from differently affected patient samples, careful individual inclusion and sampling should be performed [42]. In line with this, longitudinal designs are a better approach to establish the natural history of the disease, pinpoint predictive factors of impaired HrQoL as well as to identify pre

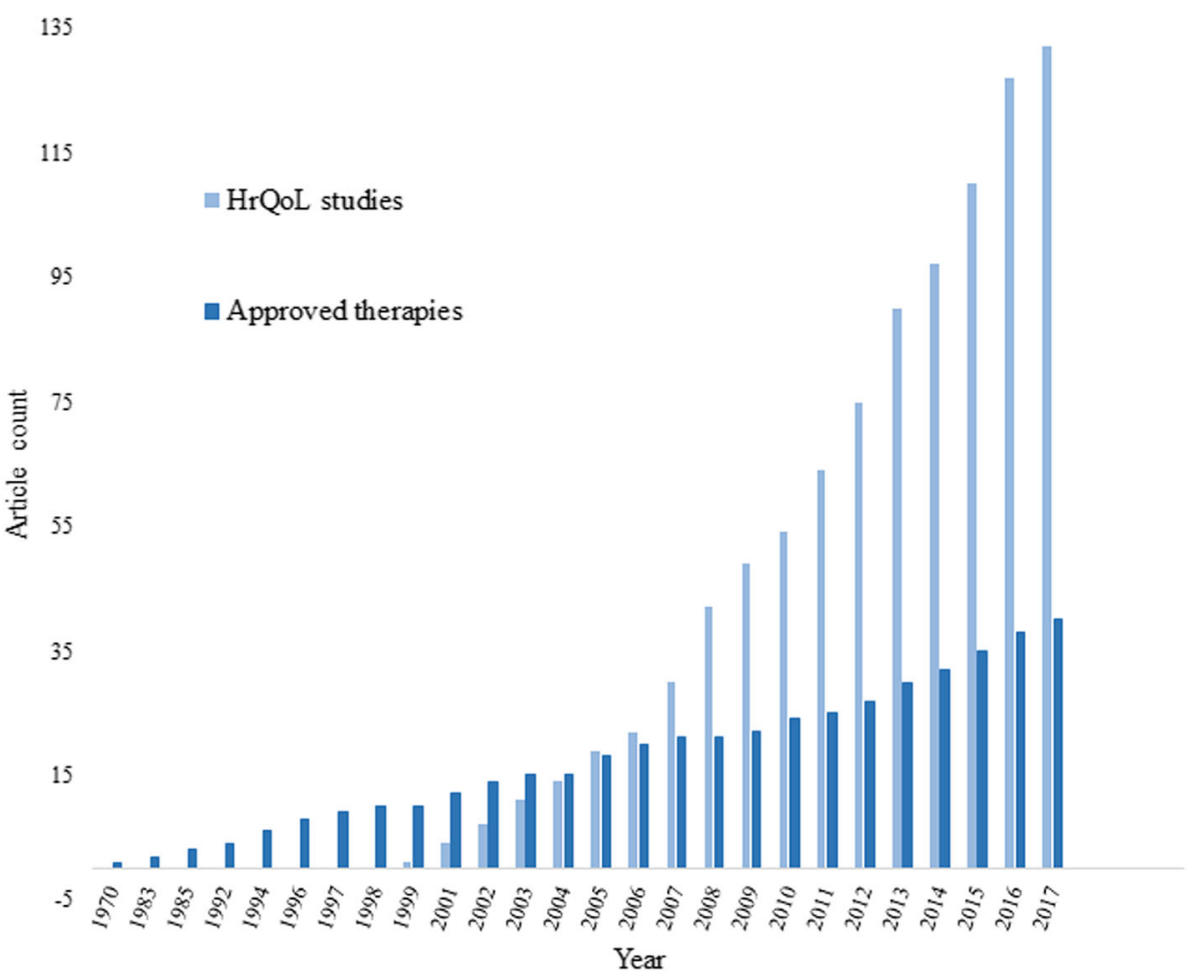

Fig. $2 \mathrm{HrQoL}$ assessment studies VS approved therapies in IMDs; Legend: Graph showing the number of HrQoL assessment studies (light blue) and approved therapies (dark blue) for the IMDs included in this review over time. The number of approved therapies is based on a specific search including EMA (http://www.ema.europa.eu), FDA (https://www.fda.gov) and Clinical Trials.gov (https://clinicaltrials.gov) 
-/post-treatment alterations [41, 43, 52, 70, 139]. Nevertheless, variability in treatment or therapy duration in long-term follow-up studies $[37,41,112,140]$ as well as previous therapies and symptom management solutions can constrain long-term analysis [44, 53, 89, 105, 110, 129, 141].

Observation of changes in HrQoL over time can be difficult due to ceiling effects (i.e. patients with scores near the upper scale limit have less room for improvement) [109, 124]. In this case, high HrQoL values have been proposed to be due to (i) the disability paradox, e.g., disabled individuals reporting good HrQoL because they focus on their coping strategies and positive emotions [46, 50, 116]; (ii) patients' expectations adaptation throughout their illness experience; (iii) adaptation by repeatedly using the same instrument [74] and (iv) variation of symptom severity [53]. Importantly, studies focusing on adult patients may often underrate the overall disease impact on HrQoL since severely affected patients may die during infancy. The spectrum of disease severity is thus not fully represented [80].

Selection bias may arise from recruitment through patient advocacy groups, health care institutions and patient registries (convenience sampling) [142]. This can cause a shift towards the inclusion of patients with either severe or milder forms of a disease who can be more or less likely to seek medical care and community support $[54,57-59,64,73,76,78,80,82,92$, 93, 96, 99, 143-146]. Volunteer participation and the patient-reported character of the questionnaires may indirectly exclude patients with poor literacy or cognition [79]. Further inherent drawbacks to patient-reported data include non-verification of diagnosis and symptomatology in medical records $[31,58,63,80,143,144,146]$, recall bias $[31,34,70$, $147]$ and social desirability [70].

\section{Discussion}

Nowadays, regulatory agencies such as FDA, EMA or health technology assessment bodies are turning to HrQoL PROMs data to support decision making. However, PROMs are not yet used routinely in clinical practice. These tools can provide natural history data, but also clinical endpoints for therapeutic trials. Consequently, there is a rise of HrQoL assessment studies using PROMs or ObsROMs in rare IMDs to fill in this gap. This reinforces the importance and need for these instruments to accelarate research and effective clinical solutions.

We identified 32 instruments used either to assess patients' HrQoL or to evaluate the risk or benefit of a specific treatment. Most of the instruments found are generic since for most IMDs, specific instruments are still inexistent. The predominant use of SF-36 is probably due to its validity in an extensive group of populations, languages, and the fact that it comprises a wide age range (14 years and older) [148]. The second most used tool was the EQ-5D, mainly within adult populations. Recently, the EuroQoL group developed the EQ-5D-Y, the child-friendly version of EQ-5D, which might increase the use of this instrument. However, until today, no population norms using EQ-5D-Y have been published. There are considerable fewer studies focused on assessing HrQoL in children. The lack of natural history studies in this population, the perception of a better health, the inability to respond for themselves, and the fact that there are much less pediatric clinical trials might be contributing factors. Nevertheless, the PedsQL and the CHQ were used in 12 and $8 \%$ of the studies respectively. The fact that these instruments can be used either as PROMs and/or ObsROMs might contribute to their frequent use compared to other pediatric tools. Frequently, studies with a combined approach of selfand proxy-reports are carried out in this population. This is even more common in disorders presenting cognitive developmental disability. Also important is the reduced ability of young children to identify issues in emotional functioning [83]. Proxy reports can accurately reflect the same aspects as observed in patients. However, they can also reflect the parent's state of mind, fears and doubts regarding their children, which results in lower HrQoL scores [46]. Therefore, self and proxy HrQoL data should be acquired and compared.

Due to the great symptom heterogeneity found among IMDs, we cannot however grade the 32 instruments found accordingly to their appropriateness to use in these disorders. Therefore, the research team should always look for the conceptual design of each instrument and analyse if it is suitable for the features of the patient population under assessment.

Generic instruments present some advantages. They can be applied to every disease or clinical manifestation and allow comparisons between different patient groups or between patients and healthy populations. However, they are not directed to the features of each condition. This may omit meaningful clinical outcomes limiting the study power $[36,46,47,50,62$, 64, 77, 147]. Disease-specific instruments include relevant questions related to a particular disease and thus are more responsive and sensitive [149]. However, they only confer the capability of making comparisons within the same patient group. Only two studies applied disease-specific tools, namely PKU-QOL and PKU-QOLQ $[89,124]$. This fact further highlights the lack of specific HrQoL PROMs in the field of IMDs. As disease-specific and generic instruments assess different aspects of $\mathrm{HrQoL}$, the use of both instruments in a complementary way has been suggested [150, 151]. A new group of HrQoL instruments is arising, namely disease group-specific instruments. In the metabolic field, we identified the QoL scale for Metabolic Diseases-Parent Form. More recently, a new promising but still not validated tool was developed for pediatric patients with intoxication type inherited errors of metabolism [152]. These tools focus on common aspects of different diseases, thus allowing comparisons across related but distinct patient populations. Furthermore, they are particularly important in rare diseases since they can overcome limitations associated with small sample size.

We identified instruments capable of detecting changes in $\mathrm{HrQoL}$ compared to normative data or following 
treatment/therapy initiation while others were not responsive. Additionally, in the case of Fabry adult patients, the results of the administration of SF-36 in three different studies evaluating the same therapeutic intervention diverged [109, 110, 141]. Thus, conclusions should be drawn with caution since other variables besides the quality of the intervention may influence the results. In fact, study design, sampling methods, suitability of the HrQoL instrument for a specific population and its selection according to the study characteristics are important factors to consider in order to obtain robust and reliable results. Additionally, the illness burden in several IMDs is not always easy to prove. For example, in propionic acidemia patients, no significant changes in $\mathrm{HrQoL}$ were found in comparison with normal individuals in spite of their poor neurocognitive and psychosocial outcomes [97]. However, we cannot exclude the fact that some IMDs affect patient's HrQoL to a lesser degree. This has been observed in PKU [30, 43, 45, 93, 94] and familial hypercholesterolemia [91, 95, 96] after efficient treatment following early diagnosis. Nevertheless, although existing tools are not responsive in these subgroups, the measurement of the impact of a highly restrictive diet on patients' QoL is extremely relevant and needed. In fact, PROMs are being developed on this topic to correctly evaluate the HrQoL of these patients [24].

Promising strategies to develop specific HrQoL PROMs that efficiently capture the patient's perspective, prognosis, impactful clinical manifestations and that establish the natural history of the disease include:

- qualitative interviews with patients, their families and caregivers;

- patient registries, which also motivate patient enrolment in research projects and clinical trials [10]. The fact that Fabry disease is the condition with higher HrQoL assessment, is likely to be a direct consequence of the successful establishment of two patient registries - the Fabry Outcome Survey (NCT03289065) and the Fabry Registry (NCT00196742). Both include periodic HrQoL evaluations as a clinical outcome;

- clinical trials networks that facilitate data sharing and collaborations, ultimately improving access to the available information [153].

\section{Conclusion and future directions}

Patient-centred approaches based on patients' HrQoL are expanding by the implementation of PROMs or ObsROMs in clinical practice and research settings. However, this review makes it clear that they are still poorly utilized in the field of IMDs. There is a huge gap in the development of responsive disease-specific $\mathrm{HrQoL}$ measurement instruments that could be useful endpoints in clinical trials. To overcome the limitations inherent to the rarity of these conditions, efforts should be made not only to develop but also to adequately validate these tools. The successful establishment of international patient registry platforms might be the path with biggest potential to upgrade HrQoL studies across IMDs. They facilitate patient recruitment and uniform data collection worldwide. In line with this, the European Commission health program included a project that consists in a novel registry platform for all known IMDs - the Unified European Registry for Inherited Metabolic Disorders (https://u-imd.org/). Although there is still a long way to go as far as the proper implementation of patient-centred care is concerned, these studies and instruments are important efforts in the right direction. HrQoL assessment through PROMs and ObsROMs are an efficient way of prioritizing the patient perspective. They drive research and more rapidly create therapeutic solutions that meet the patients' needs and expectations.

\section{Additional files}

Additional file 1: Search methodology: List of the terms used to search the Pubmed database and search strategy. (DOCX $18 \mathrm{~kb}$ )

Additional file 2: Article critical appraisal: 19 items checklist for the critical appraisal of the included studies. (DOCX $71 \mathrm{~kb}$ )

\section{Abbreviations}

(Hr)QoL: (Health-related) quality of life; CHQ: Child Health Questionnaire; EMA: European Medicine Agency; EQ-5(3)D: EuroQoL five(three)-dimension; FDA: Food and Drug Administration; IMD(s): Inherited metabolic disorder(s); $\mathrm{P}(\mathrm{Obs}) \mathrm{RO}(\mathrm{M} / \mathrm{s})$ : Patient (observer) reported outcomes (measure/s); PedsQL: Pediatric Quality of Life Inventory; PKU: Phenylketonuria; SF-36: 36Item Short form health survey

\section{Acknowledgements \\ C.P. and S.B. acknowledge CDG\&Allies-PPAIN for the 5th and 6th Liliana Scien- tific Initiation Scholarship, respectively. R.F. acknowledges Fundação para a Ciên- cia e Tecnologia with the grant SFRH/BD/124326/2016 awarded to her. We also thank Prof. Liz Forbat and the members of the CDG \& Allies - Professionals and Patient Associations International Network (CDG \& Allies PPAIN), whose network expertise greatly helped in the creation of this manuscript.}

\section{Funding}

This work was supported by the $5^{\text {th }}$ and $6^{\text {th }}$ Liliana Scientific Initiation Fellowships from CDG \& Allies - Professionals and Patient Associations International Network (CDG\&Allies-PPAIN) awarded to C.P. and S.B., respectively. R.F. was funded by Fundação para a Ciência e Tecnologia with the grant SFRH/BD/124326/2016 awarded to her.

\section{Availability of data and materials}

All data generated or analysed during this study are included in this published article [and its supplementary information files].

\section{Authors' contributions \\ VRF and LB developed the concept and design of this study. CP and SB performed all the search methodology, results analysis and the writing of this manuscript. RF contributed to the result analysis, writing and to the revision of the manuscript. LB, JJ, PV, AR and DMS critically revised the manuscript for important intellectual content. All authors gave final approval of the version to be published.}

Ethics approval and consent to participate Not applicable.

Consent for publication

Not applicable. 


\section{Competing interests}

V.R.F is the president and founder of the Portuguese Association for Congenital Disorders of Glycosylation. A.R. is the president of Glycomine, Inc. The costs regarding this publication were covered by Glycomine, Inc. All other authors declare no conflict of interests.

\section{Publisher's Note}

Springer Nature remains neutral with regard to jurisdictional claims in published maps and institutional affiliations.

\section{Author details}

${ }^{1}$ Portuguese Association for Congenital Disorders of Glycosylation (CDG), Departamento Ciências da Vida, Faculdade de Ciências e Tecnologia, Universidade NOVA de Lisboa, 2829-516 Caparica, Portugal. ${ }^{2}$ CDG \& Allies Professionals and Patient Associations International Network (PPAIN), Departamento Ciências da Vida, Faculdade de Ciências e Tecnologia, Universidade NOVA de Lisboa, 2829-516 Caparica, Portugal. ${ }^{3}$ Research Unit on Applied Molecular Biosciences (UCIBIO), Departamento Ciências da Vida, Faculdade de Ciências e Tecnologia, Universidade NOVA de Lisboa, 2829-516 Lisbon, Portugal. ${ }^{4}$ Glycomine, Inc, 953 Indiana St, San Francisco, CA 94107, USA. ${ }^{5}$ Center for Metabolic Diseases, UZ and KU Leuven, Leuven, Belgium. ${ }^{6}$ Faculdade de Psicologia, Universidade de Lisboa, 1649-013 Lisbon, Portugal.

\section{Received: 15 August 2018 Accepted: 14 November 2018} Published online: 28 November 2018

\section{References}

1. Bonner N, Abetz-Webb L, Renault L, Caballero T, Longhurst H, Maurer M, et al. Development and content validity testing of a patient-reported outcomes questionnaire for the assessment of hereditary angioedema in observational studies. Health Qual Life Outcomes. 2015;13:1-15.

2. Bogart KR, Irvin VL. Health-related quality of life among adults with diverse rare disorders. Orphanet J Rare Dis. 2017;12:177.

3. Healthy People 2020. Health-Related Quality of Life and Well-Being. 2010.

4. Robbins DA, Curro FA, Fox CH. Defining patient-centricity: opportunities, challenges, and implications for clinical care and research. Ther Innov Regul Sci. 2013:47:349-55.

5. FDA. Guidance for Industry Patient-Reported Outcome Measures: Use in Medical Product Development to Support Labeling Claims Clinical/Medical Guidance for Industry Patient-Reported Outcome Measures: Use in Medica Product Development to Support Labeling Claims. Health Qual Life Outcomes. 2006:4:79. https://doi.org/10.1186/1477-7525-4-79.

6. Basch E, Bennett A V. Patient-reported outcomes in clinical trials of rare diseases. J Gen Intern Med. 2014:29 SUPPL. 3:801-803.

7. Bevans M, Ross A, Cella D. Patient-reported outcomes measurement information system (PROMIS): efficient, standardized tools to measure selfreported health and quality of life. Nurs Outlook. 2014;62:339-45.

8. Bresnahan BW, Rundell SD. Including patient-reported outcomes and patient-reported resource-use questionnaires in studies. Acad Radiol. 2014; 21:1129-37.

9. Kyte DG, Calvert M, van der Wees PJ, ten Hove R, Tolan S, Hill JC. An introduction to patient-reported outcome measures (PROMs) in physiotherapy. Physiother (United Kingdom). 2015;101:119-125.

10. Slade A, Isa F, Kyte D, Pankhurst T, Kerecuk L, Ferguson J, et al. Patient reported outcome measures in rare diseases: a narrative review. Orphanet J Rare Dis. 2018;13:1-9.

11. EMEA. Reflection paper on the regulatory guidance for the use of healthrelated quality of life (HRQL) measures in the evaluation of medicinal products. 2005

12. Dinan M, Compton $K$, Dhillon J. Use of patient-reported outcomes in randomized, double-blind, placebo-controlled clinical trials. Med Care. 2011;49:415-9.

13. Brundage M, Bass B, Davidson J, Queenan J, Bezjak A, Ringash J, et al. Patterns of reporting health-related quality of life outcomes in randomized clinical trials: implications for clinicians and quality of life researchers. Qual Life Res. 2011;20:653-64.

14. Wiklund I. Assessment of patient-reported outcomes in clinical trials: the example of health-related quality of life. Fundam Clin Pharmacol. 2004;18:351-63.

15. Zeltner NA, Huemer M, Baumgartner MR, Landolt MA. Quality of life, psychological adjustment, and adaptive functioning of patients with intoxication-type inborn errors of metabolism - a systematic review. Orphanet J Rare Dis. 2014;9:159.
16. Ridgeway $J$, Beebe TJ, Chute CG, Eton DT, Hart LA, Frost MH, et al. A brief patient-reported outcomes quality of life (PROQOL) instrument to improve patient care. PLoS Med. 2013;10:e1001548.

17. Nelson EC, Eftimovska E, Lind C, Hager A, Wasson JH, Lindblad S. Patient reported outcome measures in practice. BMJ. 2015;350 feb10 14:g7818.

18. Khangura SD, Karaceper MD, Trakadis Y, Mitchell JJ, Chakraborty P, Tingley K, et al. Scoping review of patient- and family-oriented outcomes and measures for chronic pediatric disease. BMC Pediatr. 2015;15:7.

19. Johnston BC, Miller PA, Agarwal A, Mulla S, Khokhar R, De Oliveira K, et al. Limited responsiveness related to the minimal important difference of patient-reported outcomes in rare diseases. J Clin Epidemiol. 2016;79:10-21.

20. Verstovsek S, Mesa RA, Gotlib J, Levy RS, Gupta V, DiPersio JF, et al. A double-blind, placebo-controlled trial of ruxolitinib for myelofibrosis. N Engl J Med. 2012;366:799-807.

21. Mak CM, Lee H-CH, Chan AY-W, Lam C-W. Inborn errors of metabolism and expanded newborn screening: review and update. Crit Rev Clin Lab Sci. 2013;50:142-62.

22. Bennett MJ. Newborn screening for metabolic diseases: saving children's lives and improving outcomes. Clin Biochem. 2014;47:693-4.

23. Matern D, Rinaldo P. Newborn Screening for Inherited Metabolic Disease. In: Inherited Metabolic Diseases. Berlin, Heidelberg: Springer Berlin Heidelberg; 2017. p. 421-437.

24. Eminoglu TF, Soysal SA, Tumer L, Okur I, Hasanoglu A. Quality of life in children treated with restrictive diet for inherited metabolic disease. Pediatr Int. 2013;55:428-33.

25. Huang ME, Wartella JE, Kreutzer JS. Functional outcomes and quality of life in patients with brain tumors: a preliminary report. Arch Phys Med Rehabil. 2001:82:1540-6.

26. Picavet E, Cassiman D, Hollak CE, Maertens JA, Simoens S. Clinical evidence for orphan medicinal products-a cause for concern? Orphanet J Rare Dis. 2013;8:164

27. Arksey H, O'Malley L. Scoping studies: towards a methodological framework Int J Soc Res Methodol. 2005:8:19-32.

28. Picot J, Copley V, Colquitt JL, Kalita N, Hartwell D, Bryant J. The INTRABEAM ${ }^{\oplus}$ photon radiotherapy system for the adjuvant treatment of early breast cancer: a systematic review and economic evaluation. Health Technol Assess (Rockv). 2015:19:1-190.

29. Mathiowetz NA, Groves RM. The effects of respondent rules on health survey reports. Am J Public Health. 1985;75:639-44.

30. Landolt MA, Nuoffer J-M, Steinmann B, Superti-Furga A. Quality of life and psychologic adjustment in children and adolescents with early treated phenylketonuria can be normal. J Pediatr. 2002;140:516-21.

31. Cialone J, Adams H, Augustine EF, Marshall FJ, Kwon JM, Newhouse N, et al. Females experience a more severe disease course in batten disease. J Inherit Metab Dis. 2012;35:549-55.

32. Ceravolo F, Mascaro I, Sestito S, Pascale E, Lauricella A, Dizione E, et al. Home treatment in paediatric patients with hunter syndrome: the first Italian experience. Ital J Pediatr. 2013;39:53.

33. Eggink H, Kuiper A, Peall KJ, Contarino MF, Bosch AM, Post B, et al. Rare inborn errors of metabolism with movement disorders: a case study to evaluate the impact upon quality of life and adaptive functioning. Orphanet J Rare Dis. 2014;9:177.

34. Splinter K, Niemi A-K, Cox R, Platt J, Shah M, Enns GM, et al. Impaired health-related quality of life in children and families affected by Methylmalonic Acidemia. J Genet Couns. 2016;25:936-44.

35. Brands MMG, Gungor D, van den Hout JMP, Karstens FPJ, Oussoren E, Plug I, et al. Pain: a prevalent feature in patients with mucopolysaccharidosis. Results of a cross-sectional national survey. J Inherit Metab Dis. 2015;38:323-31.

36. Kunin-Batson AS, Shapiro EG, Rudser KD, Lavery CA, Bjoraker KJ, Jones SA, et al. Long-term cognitive and functional outcomes in children with Mucopolysaccharidosis (MPS)-IH (hurler syndrome) treated with hematopoietic cell transplantation. In: JIMD Reports. 2015. p. 95-102.

37. Shapiro EG, Rudser K, Ahmed A, Steiner RD, Delaney KA, Yund B, et al. A longitudinal study of emotional adjustment, quality of life and adaptive function in attenuated MPS II. Mol Genet Metab Reports. 2016;7:32-9.

38. Vockley J, Burton B, Berry GT, Longo N, Phillips J, Sanchez-Valle A, et al. UX007 for the treatment of long chain-fatty acid oxidation disorders: safety and efficacy in children and adults following 24 weeks of treatment. Mol Genet Metab. 2017:120:370-7.

39. Storch E, Keeley M, Merlo L, Jacob M, Correia C, Weinstein D. Psychosocial functioning in youth with glycogen storage disease type I. J Pediatr Psychol. 2008;33:728-38 
40. Goker-Alpan O, Longo N, McDonald M, Shankar SP, Schiffmann R, Chang P, et al. An open-label clinical trial of agalsidase alfa enzyme replacement therapy in children with Fabry disease who are naive to enzyme replacement therapy. Drug Des Devel Ther. 2016;10:1771-81.

41. Fabre A, Baumstarck K, Cano A, Loundou A, Berbis J, Chabrol B, et al. Assessment of quality of life of the children and parents affected by inborn errors of metabolism with restricted diet: preliminary results of a cross-sectional study. Health Qual Life Outcomes. 2013;11:158. https://doi.org/10.1186/1477-7525-11-158.

42. Raluy-Callado M, Chen W-H, Whiteman DAH, Fang J, Wiklund I. The impact of hunter syndrome (mucopolysaccharidosis type II) on health-related quality of life. Orphanet J Rare Dis. 2013;8:101.

43. Cazzorla C, Cegolon L, Burlina AP, Celato A, Massa P, Giordano L, et al. Quality of life (QoL) assessment in a cohort of patients with phenylketonuria. BMC Public Health. 2014;14:1243.

44. Feldmann R, Wolfgart E, Weglage J, Rutsch F. Sapropterin treatment does not enhance the health-related quality of life of patients with phenylketonuria and their parents. Acta Paediatr. 2017;106:953-9.

45. Thimm E, Schmidt LE, Heldt K, Spiekerkoetter U. Health-related quality of life in children and adolescents with phenylketonuria: unimpaired HRQoL in patients but feared school failure in parents. J Inherit Metab Dis. 2013;36:767-72.

46. Demirdas S, Maurice-Stam H, Boelen CCA, Hofstede FC, Janssen MCH, Langendonk JG, et al. Evaluation of quality of life in PKU before and after introducing tetrahydrobiopterin (BH4); a prospective multi-center cohort study. Mol Genet Metab. 2013;110(Suppl):S49-56.

47. McGovern MM, Wasserstein MP, Giugliani R, Bembi B, Vanier MT, Mengel E, et al. A prospective, cross-sectional survey study of the natural history of Niemann-pick disease type B. Pediatrics. 2008;122:e341-9.

48. Packman W, Henderson SL, Mehta I, Ronen R, Danner D, Chesterman B, et al. Psychosocial issues in families affected by maple syrup urine disease. J Genet Couns. 2007;16:799-809.

49. Brands MMMG, Oussoren E, Ruijter GJG, Vollebregt AAM, van den Hout HMP, Joosten KFM, et al. Up to five years experience with 11 mucopolysaccharidosis type VI patients. Mol Genet Metab. 2013;109:70-6.

50. Jamiolkowski D, Kolker S, Glahn EM, Baric I, Zeman J, Baumgartner MR, et al. Behavioural and emotional problems, intellectual impairment and healthrelated quality of life in patients with organic acidurias and urea cycle disorders. J Inherit Metab Dis. 2016:39:231-41.

51. Okano Y, Kobayashi K, Ihara K, Ito T, Yoshino M, Watanabe Y, et al. Fatigue and quality of life in citrin deficiency during adaptation and compensation stage. Mol Genet Metab. 2013;109:9-13.

52. Żuraw W, Golicki D, Jurecka A, Tylki-Szymańska A. Quality of life among polish Fabry patients - a cross-sectional study quality of life among polish Fabry patients. Open Med. 2011;6:741-9.

53. Miners AH, Holmes A, Sherr L, Jenkinson C, MacDermot KD. Assessment of health-related quality-of-life in males with Anderson Fabry disease before therapeutic intervention. Qual Life Res. 2002;11:127-33.

54. Wilcox WR, Oliveira JP, Hopkin RJ, Ortiz A, Banikazemi M, FeldtRasmussen $U$, et al. Females with Fabry disease frequently have major organ involvement: lessons from the Fabry registry. Mol Genet Metab. 2008:93:112-28.

55. Bouwman MG, Maurice-Stam H, Linthorst GE, Hollak CEM, Wijburg FA, Grootenhuis MA. Impact of growing up with Fabry disease on achievement of psychosocial milestones and quality of life. Mol Genet Metab. 2011;104:308-13.

56. Oder D, Uceyler N, Liu D, Hu K, Petritsch B, Sommer C, et al. Organ manifestations and long-term outcome of Fabry disease in patients with the GLA haplotype D313Y. BMJ Open. 2016;6:e010422.

57. Gold KF, Pastores GM, Botteman MF, Yeh JM, Sweeney S, Aliski W, et al. Quality of life of patients with Fabry disease. Qual Life Res. 2002;11:317-27.

58. Street NJ, Yi MS, Bailey LA, Hopkin RJ. Comparison of health-related quality of life between heterozygous women with Fabry disease, a healthy control population, and patients with other chronic disease. Genet Med. 2006;8:346-53.

59. Hopkin RJ, Bissler J, Banikazemi M, Clarke L, Eng CM, Germain DP, et al. Characterization of Fabry disease in 352 pediatric patients in the Fabry registry. Pediatr Res. 2008;64:550-5.

60. Weinreb N, Barranger J, Packman S, Prakash-Cheng A, Rosenbloom B, Sims K, et al. Imiglucerase (Cerezyme) improves quality of life in patients with skeletal manifestations of Gaucher disease. Clin Genet. 2007;71:576-88.

61. Giraldo P, Solano V, Perez-Calvo J-I, Giralt M, Rubio-Felix D. Quality of life related to type 1 Gaucher disease: Spanish experience. Qual Life Res. 2005;14:453-62.
62. Hagemans MLC, Janssens ACJW, Winkel LPF, Sieradzan KA, Reuser AJJ, Van Doorn PA, et al. Late-onset Pompe disease primarily affects quality of life in physical health domains. Neurology. 2004;63:1688-92.

63. Gungor D, Schober AK, Kruijshaar ME, Plug I, Karabul N, Deschauer M, et al. Pain in adult patients with Pompe disease: a cross-sectional survey. Mol Genet Metab. 2013;109:371-6.

64. Gungor D, Kruijshaar ME, Plug I, Rizopoulos D, Kanters TA, Wens SCA, et al. Quality of life and participation in daily life of adults with Pompe disease receiving enzyme replacement therapy: 10 years of international follow-up. J Inherit Metab Dis. 2016:39:253-60.

65. van der Ploeg AT, Clemens PR, Corzo D, Escolar DM, Florence J, Groeneveld $\mathrm{GJ}$, et al. A randomized study of Alglucosidase alfa in late-onset Pompe's disease. N Engl J Med. 2010;362:1396-406.

66. van der Hilst JCH, Bodar EJ, Barron KS, Frenkel J, Drenth JPH, van der Meer JWM, et al. Long-term follow-up, clinical features, and quality of life in a series of 103 patients with hyperimmunoglobulinemia D syndrome. Medicine (Baltimore). 2008;87:301-10.

67. Meiser B, Dunn S, Dixon J, Powell LW. Psychological adjustment and knowledge about hereditary hemochromatosis in a clinic-based sample: a prospective study. J Genet Couns. 2005;14:453-63.

68. Millward LM, Kelly P, Deacon A, Senior V, Peters TJ. Self-rated psychosocial consequences and quality of life in the acute porphyrias. J Inherit Metab Dis. 2001;24:733-47.

69. Verhaak C, de Laat P, Koene S, Tibosch M, Rodenburg R, de Groot I, et al. Quality of life, fatigue and mental health in patients with the m.3243A > G mutation and its correlates with genetic characteristics and disease manifestation. Orphanet J Rare Dis. 2016;11:25.

70. Munguia-Izquierdo D, Santalla A, Lucia A. Cardiorespiratory fitness, physical activity, and quality of life in patients with McArdle disease. Med Sci Sports Exerc. 2015:47:799-808.

71. Ali N, Cagle S. Psychological health in adults with morquio syndrome. JIMD Rep. 2015;20:87-93.

72. Koens LH, Kuiper A, Coenen MA, Elting JWJ, de Vries JJ, Engelen M, et al. Ataxia, dystonia and myoclonus in adult patients with Niemann-pick type C. Orphanet J Rare Dis. 2016;11:121.

73. Che H, Roux C, Etcheto A, Rothenbuhler A, Kamenicky P, Linglart A, et al. Impaired quality of life in adults with $X$-linked hypophosphatemia and skeletal symptoms. Eur J Endocrinol. 2016;174:325-33.

74. Arends M, Korver S, Hughes DA, Mehta A, Hollak CEM, Biegstraaten M. Phenotype, disease severity and pain are major determinants of quality of life in Fabry disease: results from a large multicenter cohort study. J Inherit Metab Dis. 2017:41:141-9.

75. Kanters TA, Hagemans MLC, van der Beek NAME, Rutten FFH, van der Ploeg AT, Hakkaart L. Burden of illness of Pompe disease in patients only receiving supportive care. J Inherit Metab Dis. 2011:34:1045-52.

76. Hendriksz CJ, Lavery C, Coker M, Ucar SK, Jain M, Bell L, et al. Burden of disease in patients with Morquio A syndrome: results from an international patient-reported outcomes survey. Orphanet J Rare Dis. 2014;9:32.

77. Guffon N, Heron B, Chabrol B, Feillet F, Montauban V, Valayannopoulos V. Diagnosis, quality of life, and treatment of patients with hunter syndrome in the French healthcare system: a retrospective observational study. Orphanet J Rare Dis. 2015;10:43.

78. Bosch AM, Grootenhuis MA, Bakker HD, Heijmans HSA, Wijburg FA, Last BF. Living with classical Galactosemia: health-related quality of life consequences. Pediatrics. 2004;113:e423-8.

79. Hoffmann B, Dragano N, Schweitzer-Krantz S. Living situation, occupation and health-related quality of life in adult patients with classic galactosemia. J Inherit Metab Dis. 2012;35:1051-8.

80. Weber TJ, Sawyer EK, Moseley S, Odrljin T, Kishnani PS. Burden of disease in adult patients with hypophosphatasia: results from two patient-reported surveys. Metabolism. 2016;65:1522-30.

81. Maia M, Volpini BMF, dos Santos GA, Rujula MJP. Quality of life in patients with oculocutaneous albinism. An Bras Dermatol. 2015;90:513-7.

82. Ries M, Gupta S, Moore DF, Sachdev V, Quirk JM, Murray GJ, et al. Pediatric Fabry disease. Pediatrics. 2005;115:e344-55.

83. Bugescu N, Naylor PE, Hudson K, Aoki CD, Cordova MJ, Packman W. The psychosocial impact of Fabry disease on pediatric patients. J Pediatr Genet. 2016;5:141-9.

84. Neto EV, Maia Filho HS, Monteiro CB, Carvalho LM, Tonon T, Vanz AP, et al. Quality of life and adherence to treatment in early-treated Brazilian phenylketonuria pediatric patients. Brazilian J Med Biol Res. 2017;51:e6709. 
85. Guran T, Arman A, Akcay T, Kayan E, Atay Z, Turan S, et al. Cognitive and psychosocial development in children with familial hypomagnesaemia. Magnes Res. 2011;24:7-12.

86. Ulmer FF, Landolt MA, Ha Vinh R, Huisman TAGM, Neuhaus TJ, Latal B, et al. Intellectual and motor performance, quality of life and psychosocial adjustment in children with cystinosis. Pediatr Nephrol. 2009;24:1371-8.

87. Wagner M, Kramer J, Blohm E, Vergho D, Weidemann F, Breunig F, et al. Kidney function as an underestimated factor for reduced health related quality of life in patients with Fabry disease. BMC Nephrol. 2014;15:188.

88. Hoffmann B, Keshav S. Gastrointestinal symptoms in Fabry disease: everything is possible, including treatment. Acta Paediatr. 2007;96:84-6.

89. Bosch AM, Burlina A, Cunningham A, Bettiol E, Moreau-Stucker F, Koledova $E$, et al. Assessment of the impact of phenylketonuria and its treatment on quality of life of patients and parents from seven European countries. Orphanet J Rare Dis. 2015;10:80.

90. Lampe C, Jain M, Olaye A, Meesen B, Decker C, Mengel E. Relationship between patient-reported outcomes and clinical outcomes in patients with Morquio a syndrome. J Inborn Errors Metab Screen. 2015;3:232640981557618.

91. Mata N, Alonso R, Banegas JR, Zambon D, Brea A, Mata P. Quality of life in a cohort of familial hypercholesterolemia patients from the south of Europe. Eur J Pub Health. 2012:24:221-5.

92. Wyatt K, Henley W, Anderson L, Anderson R, Nikolaou V, Stein K, et al. The effectiveness and cost-effectiveness of enzyme and substrate replacement therapies: a longitudinal cohort study of people with lysosomal storage disorders. Health Technol Assess. 2012:16:1-543.

93. Simon E, Schwarz M, Roos J, Dragano N, Geraedts M, Siegrist J, et al. Evaluation of quality of life and description of the sociodemographic state in adolescent and young adult patients with phenylketonuria (PKU). Health Qual Life Outcomes. 2008;6:25.

94. Bosch AM, Tybout W, van Spronsen FJ, de Valk HW, Wijburg FA, Grootenhuis MA. The course of life and quality of life of early and continuously treated Dutch patients with phenylketonuria. J Inherit Metab Dis. 2007;30:29-34.

95. Hyttinen L, Kekalainen P, Vuorio AF, Sintonen H, Strandberg TE. Healthrelated quality of life in elderly patients with familial hypercholesterolemia. Int J Technol Assess Health Care. 2008;24:228-34.

96. de Jongh S, Kerckhoffs MC, Grootenhuis MA, Bakker HD, Heymans HSA, Last BF. Quality of life, anxiety and concerns among statin-treated children with familial hypercholesterolaemia and their parents. Acta Paediatr. 2003;92:1096-101.

97. Grunert SC, Mullerleile S, De Silva L, Barth M, Walter M, Walter K, et al. Propionic acidemia: clinical course and outcome in 55 pediatric and adolescent patients. Orphanet J Rare Dis. 2013;8:6.

98. Giraldo P, Latre P, Alfonso P, Acedo A, Alonso D, Barez A, et al. Short-term effect of miglustat in every day clinical use in treatment-naive or previously treated patients with type 1 Gaucher's disease. Haematologica. 2006;91:703-6.

99. Giraldo P, Perez-Lopez J, Nunez R, de la Puebla RF, Luno E, Saura-Grau S, et al. Patients with type 1 Gaucher disease in Spain: a cross-sectional evaluation of health status. Blood Cells Mol Dis. 2016;56:23-30.

100. Martinuzzi A, Liava A, Trevisi E, Frare M, Tonon C, Malucelli E, et al. Randomized, placebo-controlled, double-blind pilot trial of ramipril in McArdle's disease. Muscle Nerve. 2008;37:350-7.

101. Martinuzzi A, Liava A, Trevisi E, Antoniazzi L, Frare M. Chronic therapy for McArdle disease: the randomized trial with ACE inhibitor. Acta Myol. 2007;26:64-6.

102. Vielhaber S, Brejova A, Debska-Vielhaber G, Kaufmann J, Feistner $H$, Schoenfeld MA, et al. 24-months results in two adults with Pompe disease on enzyme replacement therapy. Clin Neurol Neurosurg. 2011;113:350-7.

103. Orlikowski $D$, Pellegrini $N$, Prigent $H$, Laforêt $P$, Carlier $R$, Carlier $P$, et al. Recombinant human acid alpha-glucosidase (rhGAA) in adult patients with severe respiratory failure due to Pompe disease. Neuromuscul Disord. 2011;21:477-82.

104. Mundy HR, Williams JE, Cousins AJ, Lee PJ. The effect of L-alanine therapy in a patient with adult onset glycogen storage disease type II. J Inherit Metab Dis. 2006:29:226-9

105. Favejee MM, van den Berg LEM, Kruijshaar ME, Wens SCA, Praet SFE, Pim Pijnappel WWM, et al. Exercise training in adults with Pompe disease: the effects on pain, fatigue, and functioning. Arch Phys Med Rehabil. 2015;96:817-22.

106. Roe CR, Mochel F. Anaplerotic diet therapy in inherited metabolic disease: therapeutic potential. J Inherit Metab Dis. 2006;29:332-40.

107. Eng CM, Guffon N, Wilcox WR, Germain DP, Lee P, Waldek S, et al. Safety and efficacy of recombinant human alpha-galactosidase a replacement therapy in Fabry's disease. N Engl J Med. 2001;345:9-16.

108. Eng CM, Banikazemi M, Gordon RE, Goldman M, Phelps R, Kim L, et al. A phase $1 / 2$ clinical trial of enzyme replacement in fabry disease: pharmacokinetic, substrate clearance, and safety studies. Am J Hum Genet. 2001;68:711-22.

109. Watt T, Burlina AP, Cazzorla C, Schonfeld D, Banikazemi M, Hopkin RJ, et al. Agalsidase beta treatment is associated with improved quality of life in patients with Fabry disease: findings from the Fabry registry. Genet Med. 2010;12:703-12.

110. Eto Y, Ohashi T, Utsunomiya Y, Fujiwara M, Mizuno A, Inui K, et al. Enzyme replacement therapy in Japanese Fabry disease patients: the results of a phase 2 bridging study. J Inherit Metab Dis. 2005;28:575-83.

111. Baehner F, Kampmann C, Whybra C, Miebach E, Wiethoff CM, Beck M. Enzyme replacement therapy in heterozygous females with Fabry disease: results of a phase IIIB study. J Inherit Metab Dis. 2003;26:617-27.

112. Graesdal A, Bogsrud MP, Holven KB, Nenseter MS, Narverud I, Langslet G, et al. Apheresis in homozygous familial hypercholesterolemia: the results of a follow-up of all Norwegian patients with homozygous familial hypercholesterolemia. J Clin Lipidol. 2012;6:331-9.

113. Elstein D, Dweck A, Attias D, Hadas-Halpern I, Zevin S, Altarescu G, et al. Ora maintenance clinical trial with miglustat for type I Gaucher disease: switch from or combination with intravenous enzyme replacement. Blood. 2007; 110:2296-301.

114. Giraldo P, Alfonso P, Atutxa K, Fernandez-Galan MA, Barez A, Franco R, et al. Real-world clinical experience with long-term miglustat maintenance therapy in type 1 Gaucher disease: the ZAGAL project. Haematologica. 2009; 94:1771-5.

115. Harmatz PR, Mengel E, Geberhiwot T, Muschol N, Hendriksz CJ, Burton BK, et al. Impact of elosulfase alfa in patients with morquio a syndrome who have limited ambulation: an open-label, phase 2 study. Am J Med Genet A. 2017;173:375-83.

116. Sutcliffe RP, Maguire DD, Muiesan P, Dhawan A, Mieli-Vergani G, O'Grady JG, et al. Liver transplantation for Wilson's disease: long-term results and quality-of-life assessment. Transplantation. 2003;75:1003-6.

117. Regnery C, Kornblum C, Hanisch F, Vielhaber S, Strigl-Pill N, Grunert B, et al. 36 months observational clinical study of 38 adult Pompe disease patients under alglucosidase alfa enzyme replacement therapy. J Inherit Metab Dis. 2012;35:837-45.

118. Strothotte S, Strigl-Pill N, Grunert B, Kornblum C, Eger K, Wessig C, et al. Enzyme replacement therapy with alglucosidase alfa in 44 patients with late-onset glycogen storage disease type 2: 12-month results of an observational clinical trial. J Neurol. 2010;257:91-7.

119. Aslan GK, Huseyinsinoglu BE, Oflazer P, Gurses N, Kiyan E. Inspiratory muscle training in late-onset Pompe disease: the effects on pulmonary function tests, quality of life, and sleep quality. Lung. 2016;194:555-61.

120. Beck M, Ricci R, Widmer U, Dehout F, de Lorenzo AG, Kampmann C, et al. Fabry disease: overall effects of agalsidase alfa treatment. Eur J Clin Investig. 2004;34:838-44

121. Mehta A, Beck M, Elliott P, Giugliani R, Linhart A, Sunder-Plassmann G, et al. Enzyme replacement therapy with agalsidase alfa in patients with Fabry's disease: an analysis of registry data. Lancet (London, England). 2009;374:1986-1996.

122. Hoffmann B, Garcia de Lorenzo A, Mehta A, Beck M, Widmer U, Ricci R. Effects of enzyme replacement therapy on pain and health related quality of life in patients with Fabry disease: data from FOS (Fabry Outcome Survey). J Med Genet. 2005:42:247-52.

123. Langman CB, Greenbaum LA, Grimm P, Sarwal M, Niaudet P, Deschenes $G$, et al. Quality of life is improved and kidney function preserved in patients with nephropathic cystinosis treated for 2 years with delayed-release cysteamine bitartrate. J Pediatr. 2014;165:528-33.e1.

124. Douglas TD, Ramakrishnan U, Kable JA, Singh RH. Longitudinal quality of life analysis in a phenylketonuria cohort provided sapropterin dihydrochloride. Health Qual Life Outcomes. 2013;11:218.

125. Cazzorla C, Del Rizzo M, Burgard P, Zanco C, Bordugo A, Burlina AB, et al. Application of the WHOQOL-100 for the assessment of quality of life of adult patients with inherited metabolic diseases. Mol Genet Metab. 2012;106:25-30.

126. Gargiulo M, Herson A, Michon CC, Hogrel JY, Doppler V, Laloui K, et al. Attitudes and expectations of patients with neuromuscular diseases about their participation in a clinical trial. Rev Neurol (Paris). 2013;169:670-6.

127. Tsuboi $\mathrm{K}$, Yamamoto $\mathrm{H}$. Clinical course of patients with Fabry disease who were switched from agalsidase-beta to agalsidase-alpha. Genet Med. 2014; 16:766-72.

128. Oliveira FL, Alegra T, Dornelles A, Krug BC, Netto CBO, da Rocha NS, et al. Quality of life of Brazilian patients with Gaucher disease and Fabry disease. In: JIMD reports; 2012. p. 31-7. 
129. Hughes DA, Deegan PB, Milligan A, Wright N, Butler LH, Jacobs A, et al. A randomised, double-blind, placebo-controlled, crossover study to assess the efficacy and safety of three dosing schedules of agalsidase alfa enzyme replacement therapy for Fabry disease. Mol Genet Metab. 2013;109:269-75.

130. Pisani A, Spinelli L, Visciano B, Capuano I, Sabbatini M, Riccio E, et al. Effects of switching from Agalsidase Beta to Agalsidase alfa in 10 patients with Anderson-Fabry disease. In: JIMD reports; 2012. p. 41-8.

131. Kanters TA, Redekop WK, Kruijshaar ME, van der Ploeg AT, Rutten-van Molken MPMH, Hakkaart L. Comparison of EQ-5D and SF-6D utilities in Pompe disease. Qual Life Res. 2015;24:837-44.

132. Smid BE, Rombach SM, Aerts JMFG, Kuiper S, Mirzaian M, Overkleeft HS, et al. Consequences of a global enzyme shortage of agalsidase beta in adult Dutch Fabry patients. Orphanet J Rare Dis. 2011;6:69.

133. Bik-Multanowski M, Didycz B, Mozrzymas R, Nowacka M, Kaluzny L, Cichy W, et al. Quality of life in noncompliant adults with phenylketonuria after resumption of the diet. J Inherit Metab Dis. 2008;31(Suppl 2):S415-8.

134. Muenzer J, Beck M, Eng CM, Giugliani R, Harmatz P, Martin R, et al. Longterm, open-labeled extension study of idursulfase in the treatment of hunter syndrome. Genet Med. 2011;13:95-101.

135. Tsuboi K, Yamamoto H. Clinical observation of patients with Fabry disease after switching from agalsidase beta (Fabrazyme) to agalsidase alfa (Replagal). Genet Med. 2012;14:779-86.

136. Wild D, Eremenco S, Mear I, Martin M, Houchin C, Gawlicki M, et al. Multinational trials-recommendations on the translations required, approaches to using the same language in different countries, and the approaches to support pooling the data: the ISPOR patient-reported outcomes translation and linguistic validation good research practices task force report. Value Heal. 2009;12:430-40. https://doi.org/10.1111/j. 1524-4733.2008.00471.x.

137. Sechi A, Deroma L, Paci S, Lapolla A, Carubbi F, Burlina A, et al. Quality of life in adult patients with glycogen storage disease type I: results of a multicenter italian study. JIMD Rep. 2014;14:47-53.

138. Clarke LA, Wraith JE, Beck M, Kolodny EH, Pastores GM, Muenzer J, et al. Long-term efficacy and safety of laronidase in the treatment of mucopolysaccharidosis I. Pediatrics. 2009;123:229-40.

139. Gunther P, Hermann W, Kuhn H-J, Wagner A. Wilson's disease. Ther Umsch. 2007;64:57-61.

140. Schaefer M, Gotthardt DN, Ganion N, Wohnsland S, Seessle J, Stremmel W, et al. Wilson disease: health-related quality of life and risk for depression. Clin Res Hepatol Gastroenterol. 2016;40:349-56.

141. Koskenvuo JW, Hartiala JJ, Nuutila P, Kalliokoski R, Viikari JS, Engblom E, et al. Twenty-four-month alpha-galactosidase a replacement therapy in Fabry disease has only minimal effects on symptoms and cardiovascular parameters. J Inherit Metab Dis. 2008:31:432-41.

142. Elfil M, Negida A. Sampling methods in Clinical Research; an Educational Review. Emerg (Tehran, Iran). 2017;5:e52.

143. Modersitzki F, Pizzi L, Grasso M, Goldfarb DS. Health-related quality of life (HRQoL) in cystine compared with non-cystine stone formers. Urolithiasis. 2014;42:53-60.

144. de Graaff B, Neil A, Sanderson K, Yee KC, Palmer AJ. Quality of life utility values for hereditary haemochromatosis in Australia. Health Qual Life Outcomes. 2016;14:31.

145. Laney DA, Gruskin DJ, Fernhoff PM, Cubells JF, Ousley OY, Hipp H, et al. Social-adaptive and psychological functioning of patients affected by Fabry disease. J Inherit Metab Dis. 2010;33(Suppl 3):S73-81.

146. Péntek M, Gulácsi L, Brodszky V, Baji P, Boncz I, Pogány G, et al. Social/ economic costs and health-related quality of life of mucopolysaccharidosis patients and their caregivers in Europe. Eur J Health Econ. 2016;17:89-98.

147. Ghali J, Nicholls K, Denaro C, Sillence D, Chapman I, Goldblatt J, et al. Effect of reduced Agalsidase Beta dosage in Fabry patients: the Australian experience. In: JIMD reports; 2011. p. 33-43.

148. Ware JE, Sherbourne CD. The MOS 36-item short-form health survey (SF-36). I. Conceptual framework and item selection. Med Care. 1992;30:473-83.

149. Wiebe S, Guyatt G, Weaver B, Matijevic S, Sidwell C. Comparative responsiveness of generic and specific quality-of-life instruments. J Clin Epidemiol. 2003;56:52-60.

150. Assari S, Lankarani MM, Montazeri A, Soroush MR, Mousavi B. Are generic and disease-specific health related quality of life correlated? The case of chronic lung disease due to sulfur mustard. J Res Med Sci. 2009;14:285-90.

151. Malý M, Vondra V. Generic versus disease-specific instruments in quality-oflife assessment of chronic obstructive pulmonary disease. Methods Inf Med. 2006;45:211-5
152. Zeltner NA, Baumgartner MR, Bondarenko A, Ensenauer R, Karall D, Kolker S, et al. Development and psychometric evaluation of the MetabQoL 1.0: a quality of life questionnaire for Paediatric patients with intoxication-type inborn errors of metabolism. JIMD Rep. 2017;37:27-35.

153. Wastfelt M, Fadeel B, Henter J-I. A journey of hope: lessons learned from studies on rare diseases and orphan drugs. J Intern Med. 2006;260:1-10.

154. Barba-Romero MA, Rivera-Gallego A, Pintos-Morell G. Fabry disease in Spain: description of Spanish patients and a comparison with other European countries using data from the Fabry outcome survey (FOS). Int J Clin Pract. 2011;65:903-10.

155. Rombout-Sestrienkova E, Winkens B, Essers BAB, Nieman FHM, Noord PAH, Janssen $\mathrm{MCH}$, et al. Erythrocytapheresis versus phlebotomy in the maintenance treatment of HFE hemochromatosis patients: results from a randomized crossover trial. Transfusion. 2016;56:261-70.

156. Concolino D, Amico L, Cappellini MD, Cassinerio E, Conti M, Donati MA, et al. Home infusion program with enzyme replacement therapy for Fabry disease: the experience of a large Italian collaborative group. Mol Genet Metab reports. 2017;12:85-91.

157. Maselbas W, Chabik G, Czlonkowska A. Persistence with treatment in patients with Wilson disease. Neurol Neurochir Pol. 2010;44:260-3.

158. Bonnefont J-P, Bastin J, Behin A, Djouadi F. Bezafibrate for an inborn mitochondrial beta-oxidation defect. N Engl J Med. 2009;360:838-40.

159. Wang RY, Lelis A, Mirocha J, Wilcox WR. Heterozygous Fabry women are not just carriers, but have a significant burden of disease and impaired quality of life. Genet Med. 2007:9:34-45.

160. Hughes DA, Nicholls K, Shankar SP, Sunder-Plassmann G, Koeller D, Nedd K, et al. Oral pharmacological chaperone migalastat compared with enzyme replacement therapy in Fabry disease: 18-month results from the randomised phase III ATTRACT study. J Med Genet. 2017;54:288-96.

161. Kantola I, Hietaharju A, Taurio J, Kananen K, Kantola T, Viikari J. P08-QUALITY OF LIFE DID NOT WORSEN FOR 7 YEARS IN ENZYME-REPLACEMENT THERAPY RECIPIENTS WITH FABRY DISEASE. Clin Ther. 2012;34:e21-2.

162. Germain DP, Hughes DA, Nicholls K, Bichet DG, Giugliani R, Wilcox WR, et al. Treatment of Fabry's disease with the pharmacologic chaperone Migalastat. N Engl J Med. 2016;375:545-55.

163. Pastores GM, Barnett NL, Bathan P, Kolodny EH. A neurological symptom survey of patients with type I Gaucher disease. J Inherit Metab Dis. 2003;26:641-5.

164. Kishnani PSS, DiRocco M, Kaplan P, Mehta A, Pastores GMM, Smith SEE, et al. A randomized trial comparing the efficacy and safety of imiglucerase (Cerezyme) infusions every 4 weeks versus every 2 weeks in the maintenance therapy of adult patients with Gaucher disease type 1. Mol Genet Metab. 2009;96:164-70.

165. Wenzel LB, Anderson R, Tucker DC, Palla S, Thomson E, Speechley M, et al Health-related quality of life in a racially diverse population screened for hemochromatosis: results from the hemochromatosis and Iron overload screening (HEIRS) study. Genet Med. 2007:9:705-12.

166. Cotugno G, Nicolo R, Cappelletti S, Goffredo BM, Dionisi Vici C, Di Ciommo $V$. Adherence to diet and quality of life in patients with phenylketonuria. Acta Paediatr. 2011;100:1144-9.

167. Masek BJ, Sims KB, Bove CM, Korson MS, Short P, Norman DK. Quality of life assessment in adults with type 1 Gaucher disease. Qual Life Res. 1999;8:263-8.

168. Angelini $C$, Semplicini $C$, Tonin $P$, Filosto $M$, Pegoraro $E$, Sorarù $G$, et al. Progress in enzyme replacement therapy in glycogen storage disease type II. Ther Adv Neurol Disord. 2009;2:143-53.

169. Merk T, Wibmer T, Schumann C, Kruger S. Glycogen storage disease type II (Pompe disease)--influence of enzyme replacement therapy in adults. Eur J Neurol. 2009;16:274-7.

170. Svetel M, Pekmezovic T, Tomic A, Kresojevic N, Potrebic A, Jesic R, et al. Quality of life in patients with treated and clinically stable Wilson's disease. Mov Disord. 2011;26:1503-8.

171. Komal Kumar RN, Taly AB, Nair KPS, Sinha S, Prashanth LK, Vidya N, et al. Quality of life in Wilson's disease. Ann Indian Acad Neurol. 2008;11:37-40. 